\title{
National Register of Historic Places Eligibility Testing of 41BX1764 (The Dos Mujeres Site), Bexar County, Texas
}

Antonia L. Figueroa

Center for Archeological Research, University of Texas at San Antonio

Follow this and additional works at: https://scholarworks.sfasu.edu/ita

Part of the American Material Culture Commons, Archaeological Anthropology Commons, Environmental Studies Commons, Other American Studies Commons, Other Arts and Humanities Commons, Other History of Art, Architecture, and Archaeology Commons, and the United States History Commons

Tell us how this article helped you.

This Article is brought to you for free and open access by the Center for Regional Heritage Research at SFA ScholarWorks. It has been accepted for inclusion in Index of Texas Archaeology: Open Access Gray Literature from the Lone Star State by an authorized editor of SFA ScholarWorks. For more information, please contact cdsscholarworks@sfasu.edu. 


\section{National Register of Historic Places Eligibility Testing of 41BX1764 (The Dos Mujeres Site), Bexar County, Texas}

\section{Creative Commons License}

\section{(c) (1) (8)}

This work is licensed under a Creative Commons Attribution-NonCommercial 4.0 International License 


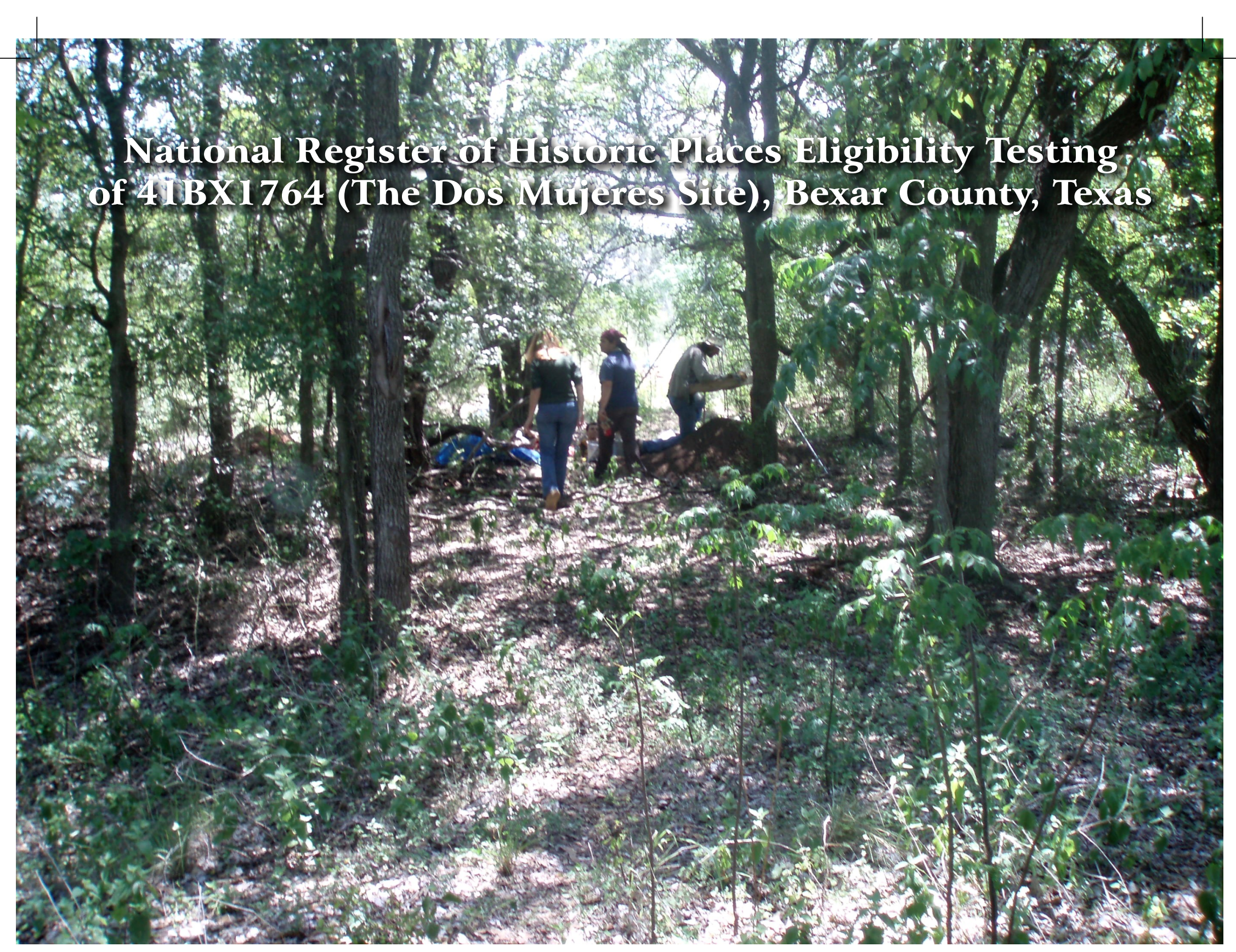

by

Antonia L. Figueroa

Texas Antiquities Permit No. 4989

Prepared for:

Adams Environmental Incorporated 12018 Las Nubes

San Antonio, Texas 78233

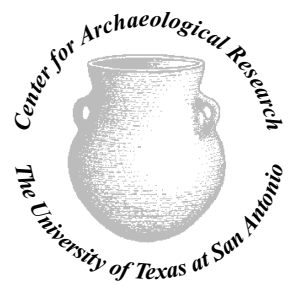

Prepared by:

Center for Archaeological Research The University of Texas at San Antonio Archaeological Report, No. 398 


\title{
National Register of Historic Places Eligibility Testing of 41BX1764 (The Dos Mujeres Site), Bexar County, Texas
}

\author{
by
}

Antonia L. Figueroa

Texas Antiquities Committee Permit No. 4989

\author{
Principal Investigator \\ Cynthia M. Muñoz
}

Prepared for:

Adams Environmental Incorporated 12018 Las Nubes San Antonio, Texas 78233
Prepared by:

Center for Archaeological Research The University of Texas at San Antonio Archaeological Report No. 398 



\begin{abstract}
:
The Center for Archaeological Research (CAR) of The University of Texas at San Antonio conducted National Register of Historic Places (NRHP) eligibility testing at site 41BX1764. The archaeological testing associated with the Salado Creek Greenway project located in San Antonio, Bexar County, Texas was completed to fulfill contract requirements with Adams Environmental, Inc. of San Antonio. The survey was conducted under the requirements of the City of San Antonio Unified Development Code Chapter 35, Section 106 of the National Historic Preservation Act (NHPA) of 1966, and the Texas Antiquities Code. The archaeological testing was performed under Texas Antiquities Permit No. 4989, with Cynthia M. Muñoz, serving as Principal Investigator and Antonia L. Figueroa serving as Project Archaeologist. The work was conducted in advance of construction of a multi-use greenway trail proposed by the Parks and Recreation Department of the City of San Antonio.
\end{abstract}

Results from testing revealed a multi-component site with a Late Prehistoric Toyah component. A deeper second component, of unknown date, was also identified. The Late Prehistoric component has been impacted by erosion and the existing trail, while the lower component appears to be in a secondary depositional context. No features were revealed during testing and the CAR does not recommend the site as eligible for the National Register of Historic Places (NRHP) or for formal designation as a State Archeological Landmark.

All materials recovered during the investigation and all project related documents are curated at the Center for Archaeological Research. 


\section{Table of Contents:}

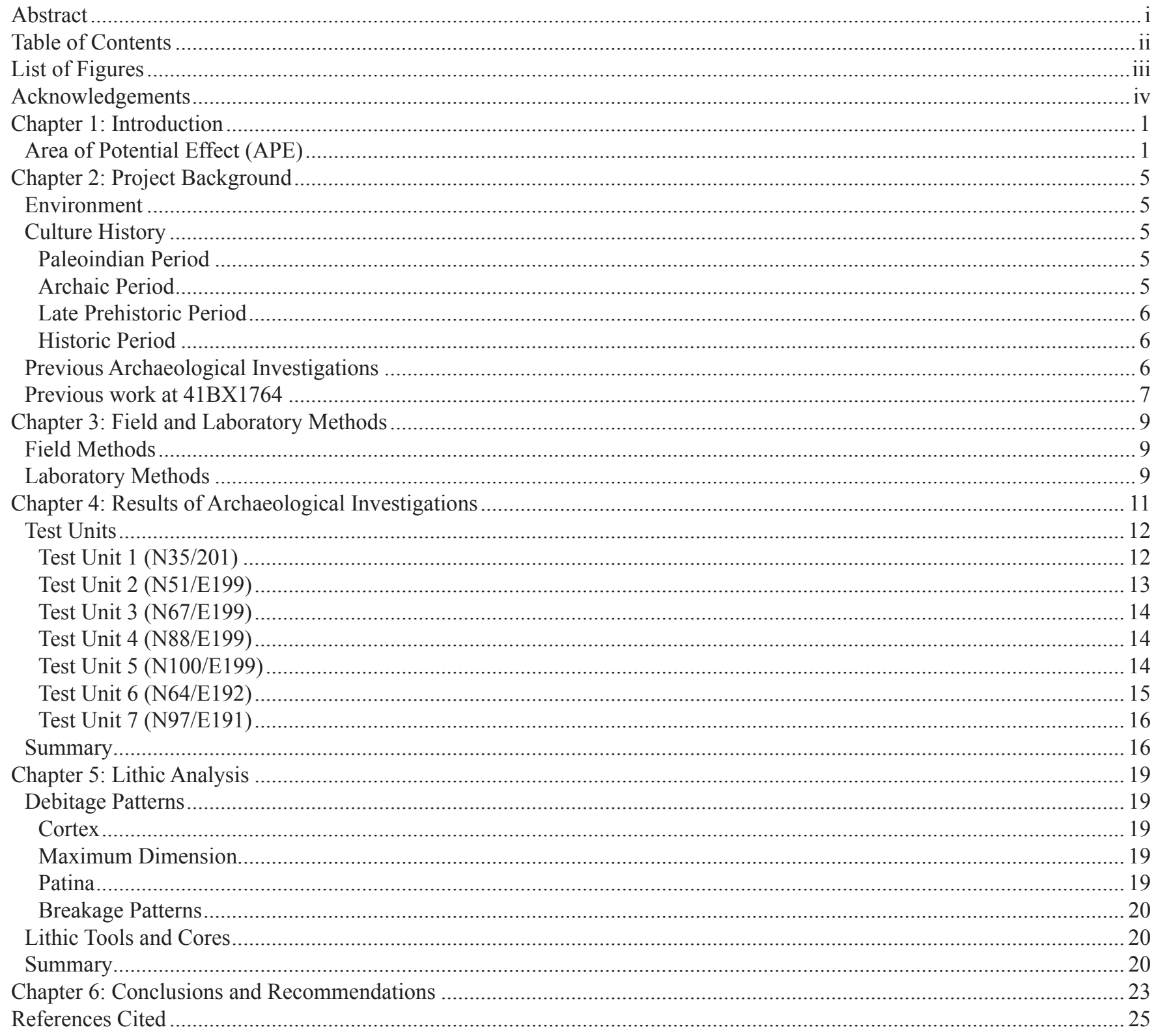




\section{List of Figures:}

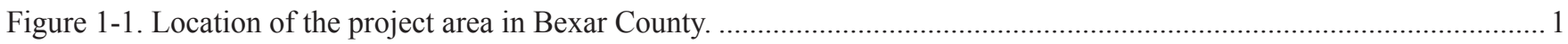

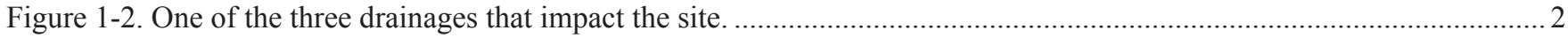

Figure 1-3. The existing trail runs along the eastern margin of the site. ........................................................................

Figure 4-1. Site map of 41BX1764 showing test units, Phase I shovel tests, and other impacts to the site. .......................... 11

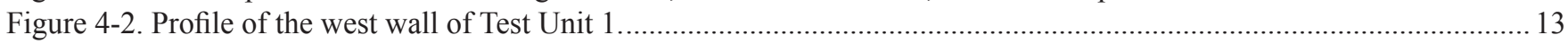

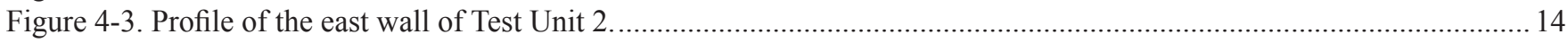

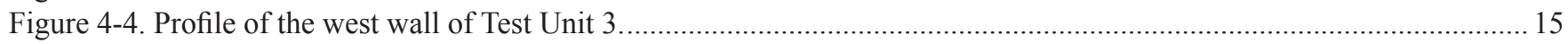

Figure 4-5. Profile of the west all of Test Unit 4

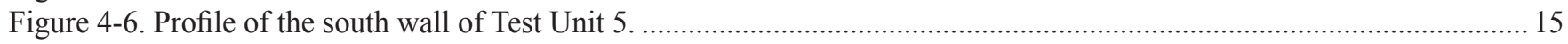

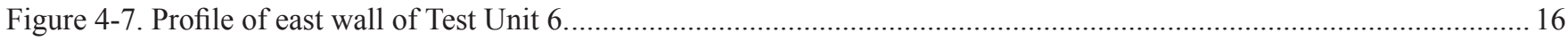

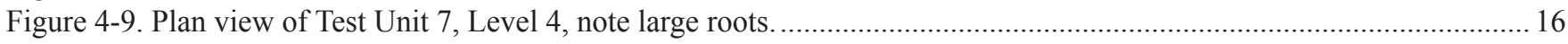

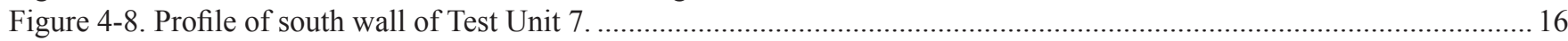

Figure 4-10. Site map of 41BX1764 with bar chart showing prehistoric artifact counts per test unit. ................................ 17

Figure 5-1. Lithic tools recovered from test unit excavations: a-b)biface, c) fragment of beveled knife. .............................221

\section{List of Tables:}

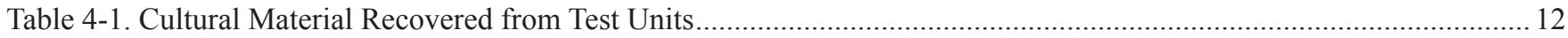

Table 5-1. Cortex Percentages for the Late Prehistoric Component and Lower Component .................................................. 19

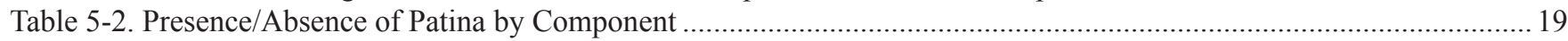

Table 5-3. Flake Fragment Percentages for Tool versus Core Reduction Assemblages .......................................................220

Table 5-3. Flake Fragment Percentages for Tool versus Core Reduction Assemblages .......................................................20

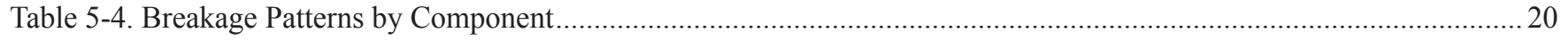




\section{Acknowledgements:}

The completion of this project would not have been possible without the field crew. They included the following individuals from the Center for Archaeological Research: Nathan Devito, Cyndi Dickey, Jon Dowling, Jason Perez, and Joseph Thompson. Jennifer Mate, an intern of CAR, generously volunteered her time and aided in the field. Cynthia Moore Munoz served as Principal Investigator on the project and gave comments on the draft report. Dr. Raymond Mauldin provided input during the testing. The artifacts and project related documents were processed by Bryant Saner and Jason Perez. The lab processes were overseen by Marybeth Tomka. The author would also like to thank Bruce Moses for aiding with field logistics, drafting report figures, and producing the final manuscript. The author thanks Brian Gottschalk and Lynn Kitchen, both of Adams Environmental, Inc., and Kay Hindes, Archaeologist for the City of San Antonio. 


\section{Chapter 1: Introduction}

The Center for Archaeological Research (CAR) of The University of Texas at San Antonio was contracted by Adams Environmental Inc. of San Antonio to conduct National Register of Historic Places (NRHP) eligibility testing of site 41BX1764 for the Salado Creek Greenway project located in San Antonio, Bexar County, Texas (Figure 1-1). The eligibility testing was conducted in August 2008 in advance of the proposed construction of a hike and bike trail. The main goal of the NRHP eligibility testing was to: 1) determine the extent, nature, and depth of the deposits; and 2) determine if the site warrants listing on the NRHP and/or designation as a State Archeological Landmark (SAL). The archaeological testing was performed under Texas Antiquities Permit No. 4989, with Cynthia M. Muñoz serving as Principal Investigator and Antonia L. Figueroa serving as Project Archaeologist.

Seven 1-x-1 meter units were excavated during the testing of site 41BX1764. Over 600 artifacts were recovered from the site, the majority consisting of lithic debitage. Eight lithic tools, including one diagnostic, and two cores were collected. The diagnostic tool, unearthed $30-40 \mathrm{cmbs}$, is a beveled knife associated with the Late Prehistoric period. Two components, an upper, Late Prehistoric deposit and a lower deposit, of unknown temporal affiliation, were identified. No features were found during testing of the site. Moreover, erosion associated with two ephemeral drainages and preexisting trail has impacted the eastern margins of the site. The CAR does not recommend the site for listing on the NRHP or as a SAL.

The land impacted by the project is owned by the City of San Antonio, a political subdivision of the State of Texas. As such, the project has to comply with the State Historic Preservation laws and specifically mandates of the Antiquities Code of Texas. The project falls under the oversight of the Texas Historical Commission. The work was also coordinated through the City's Historic Preservation Office in compliance with the City of San Antonio Unified Development Code, Chapter 35. In addition, because the project area is located along a waterway and a bridge will have to be constructed across Salado Creek, a 404 Nationwide Permit will have to be issued by the Corps of Engineers (COE).

\section{The Project Background and Area of Potential Effect (APE)}

Site 41BX1764, located within the Salado watershed, is in north-central San Antonio south of Nacogdoches Road and north of Loop 410. The site is situated on the western descending banks of the Salado Creek channel on a T2 terrace. Three small drainages, running west to east, cross the site. One bisects the site and two mark the northern and southern boundaries (Figure 1-2). The eastern portion of the site has been impacted by an existing trail (Figure 1-3). The proposed trail corridor associated with the Salado Greenway Project will be along the pre-existing trail. 41BX1764 occupies 2625 square meters.

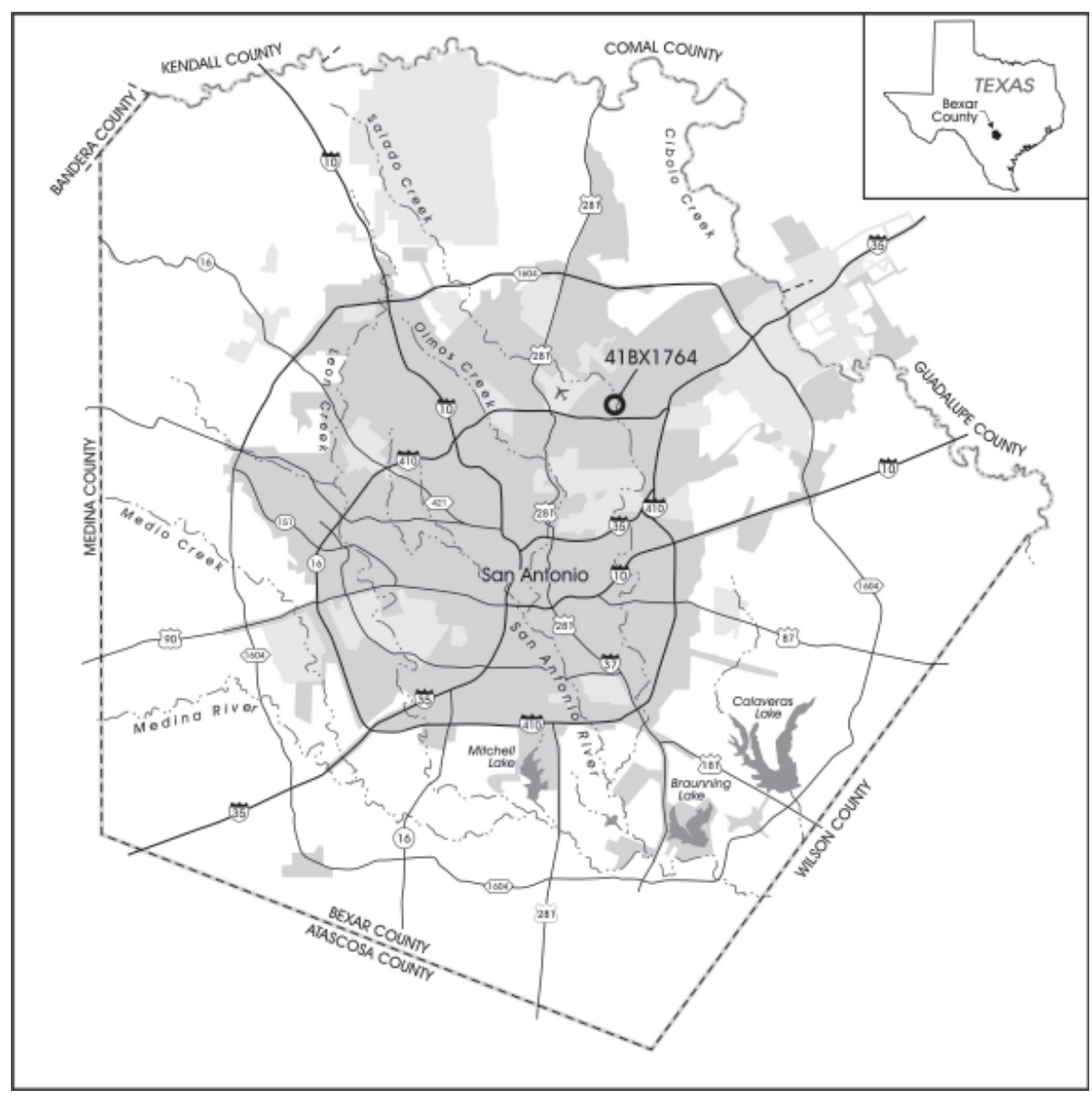

Figure 1-1. Location of the project area in Bexar County. 


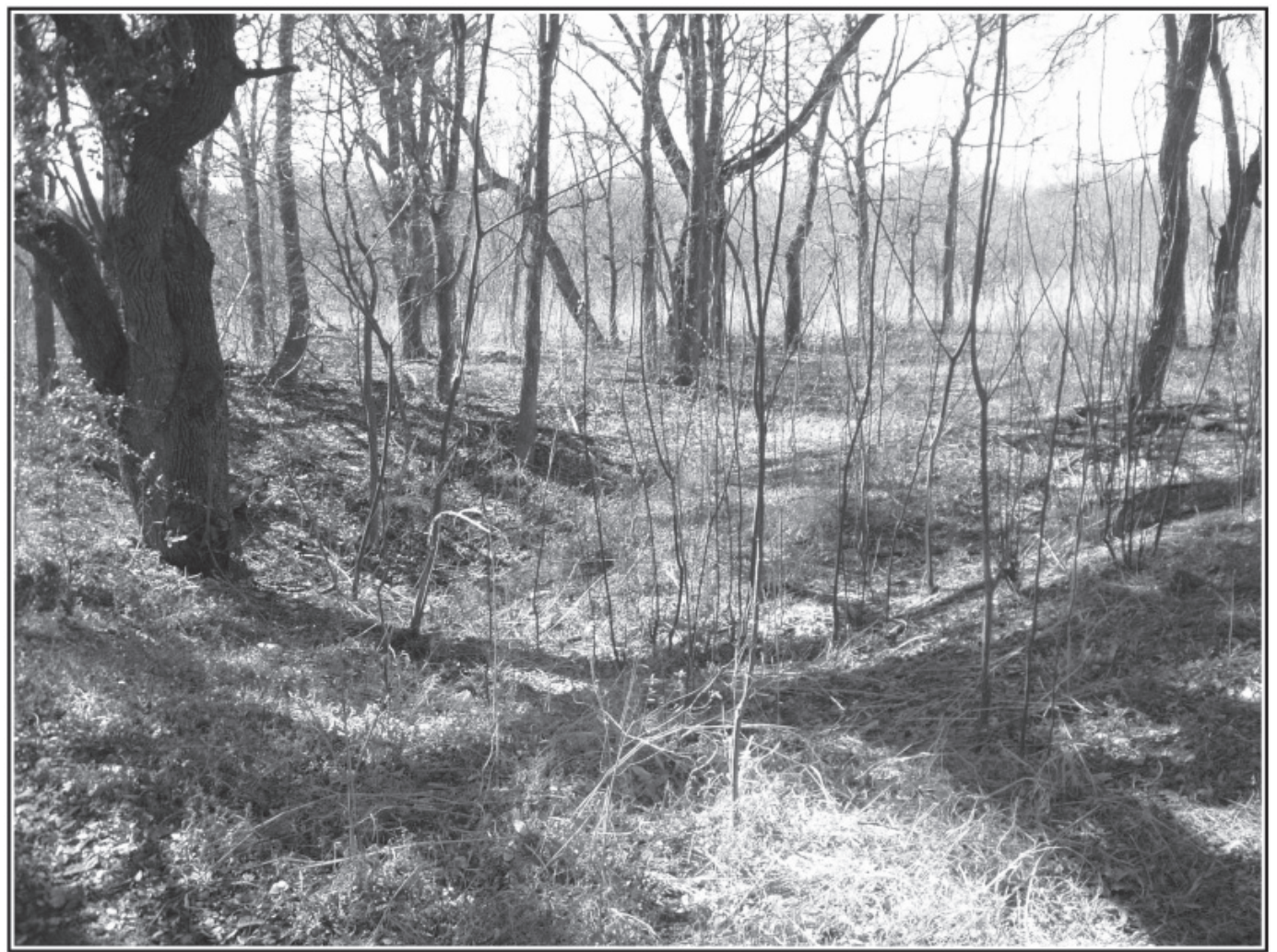

Figure 1-2. One of the three drainages that impact the site.

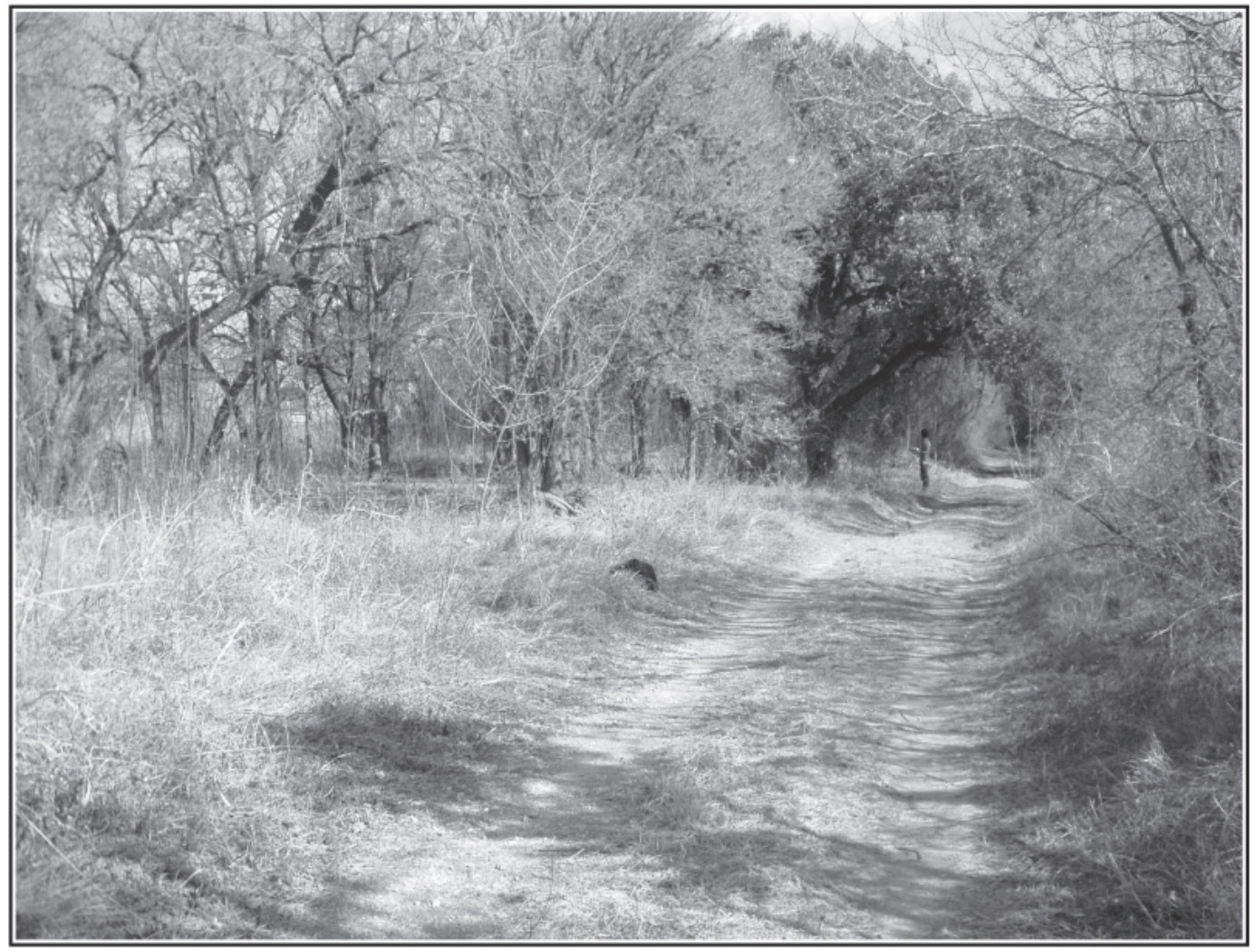

Figure 1-3. The existing trail runs along the eastern margin of the site. 
The site was documented during the second phase of the archaeological survey of the Salado Creek Greenway project (Figueroa 2008). The Greenway project consists of a multiuse greenway trail, trailhead, trail switchbacks, signage, and a parking lot. Signage along the trail and at the trail head will require footings that could go as deep as 24 to 36 inches $(.61-.91 \mathrm{~m})$. The right-of-way (ROW) is approximately 20 meters in width but varies in different parts of the project area. The proposed project is part of the City's long-range plan to maintain, improve, and expand existing multi-use greenway trails. The first phase of the survey spanned from N.E. Loop 410 south to Eisenhauer Road (Munoz 2008) and measured roughly two miles (3,219 meters). The second phase covered approximately two and a half miles $(4,023$ meters) from Loop 410 north to Wetmore Avenue (Figueroa 2008). A third segment of the trail corridor continues from Wetmore Avenue into McAllister Park. This section has been addressed in previous archaeological investigations (Figueroa and Thompson 2005). 



\section{Chapter 2: Project Background}

The project area is located in northeast Bexar County, San Antonio, Texas. This chapter discusses the project area environs, including the Salado Creek watershed, physiographic region, vegetation and soils. The culture history for southcentral Texas and a summary of the previous archaeology in the area are also included.

\section{Environment}

The project area is within a transitional zone between two major physiographic regions: the Balcones Escarpment and the Edward's plateau (Black 1989). These physiographic regions contain biotic zones that represent prime environments for a variety of flora and fauna. Limestone foothills that represent the Balcones Escarpment extend from northern Bexar County southwest into the area of Del Rio, on the Rio Grande River. The topography is represented by rugged terrain in the form of low steep hills cross-cut by several small intermittent streams.

Vegetation in the area consists of typical South Texas scrub and grass species, including mesquite (Prosopis juliflora var. glandulosa), live oak (Quercus virgininana), pecan (Carya illnoinensis), Texas persimmion (Diospyros texana) and prickly pear cactus (Opuntia engelmanni; Vines 1960).

Potter et al. (1995) have divided the Salado Creek System into Upper, Middle and Lower reaches. The three sections of the Salado watershed are classified by stream gradient and depositional patterns. The project area is within the Middle Salado watershed (Potter et al. 1995). The Middle Salado is defined as a 25 linear $\mathrm{km}$ portion of the drainage that begins at its confluence with Panther Springs and ends $20 \mathrm{~km}$ above its confluence with the San Antonio River.

The soils in the immediate vicinity of the active channel are described as frequently flooded Trinity and Frio Soils (Tf). These soils occur as narrow, irregularly shaped areas on the flood plains of small streams and large drainages. Trinity/ Frio soils range from one to one and one half meters deep and consist of a surface layer of clay loam and a subsurface layer of clay with pockets of thin loamy strata (Taylor et al. 1991). The soils abutting the active channel are identified as Lewisville silty clays (Lv), Patrick soils (Pa), and Tarrant association (Ta). The Lewisville series consist of moderately deep, dark colored, alluvial soils. Patrick soils contain shallow, calcareous clay loam. The Tarrant series are characterized by gently undulating, stony, clay loam overlying shallow bedrock. A small segment of the soils adjacent to the active channel near the southern end of the project area is identified as Pits and Quarries (Pt). This land type consists of clay, gravel and sand pits, limestone, chalk and rock quarries, and city dumps (Taylor et al. 1991).

\section{Culture History}

The culture history of the region spans nearly 11,500 years. There are four culture periods that are discernable by changes in hunting and gathering technologies and material culture: Paleoindian, Archaic, Late Prehistoric and Historic. Culture histories of both South and Central Texas were used in developing this section of the report, with primary sources including Collins (1995) and Hester (1995).

\section{Paleoindian Period}

The earliest documentation of humans in Texas occurred during the Paleoindian period which dates from 11,500-8800 BP (Collins 1995). This period is further divided into early and late Paleoindian subperiods. Material culture from the early Paleoindian includes Clovis and Folsom fluted projectile points utilized in hunting of megafauna. Although exploiting megafauna was one form of subsistence, systematic reliance on medium to small size game and plants was probably more common. Unfluted points such as Golondrina and Scottsbluff, are diagnostic of the late Paleoindian. The marked changes in lithic technology coincided with changes in species hunted.

\section{Archaic Period}

This period spans from ca. $8800-1150 \mathrm{BP}$ and is distinguished by three subperiods: Early Archaic, Middle Archaic and Late Archaic. During the Archaic period there was a shift in subsistence to a greater emphasis on the exploitation of specific local environments. Hunting strategies focused mainly on medium to small game. The ecological changes that occurred throughout the long span of the Archaic period could account for the changes in material culture (Collins 1995).

Hester (1995:436-438) places the Early Archaic between 7950 and 4450 BP based on Early Corner Notched and Early Basal Notched projectile points. Collins (1995:383) dates the Early Archaic period from 8800 to 6000 BP based initially 
on unstemmed point types such as the Angostura. Middle Archaic materials date from about 6000 to $4000 \mathrm{BP}$, with increased occurrence of multi-use bifacial knives and burned rock middens (Collins 1995:383). Diagnostic points from this period include Bell, Andice, Taylor, Nolan, and Travis. The last interval of the Archaic falls between 4000-1150 BP (Collins 1995:384). Dart point diagnostics of the Late Archaic are somewhat smaller, triangular points with corner notches such as the Ensor and Ellis (Turner and Hester 1993). Other Late Archaic points include Bulverde, Pedernales, Marshall, and Marcos (Collins 1995).

\section{Late Prehistoric Period}

This period extends from ca. 1150-350 BP (Collins 1995) and is marked by the introduction of the bow and arrow. Austin and Toyah Phases subdivide this culture period. A series of distinctive traits mark the shift from the Archaic to the Late Prehistoric period, including the technological shift to the bow and arrow and the introduction of pottery. During the Austin Phase there was an increase in the use of burned rock middens (Black and Creel 1997). Diagnostic point types include Scallorn and Edwards (Collins 1995; Turner and Hester 1993). The Toyah Phase of the Late Prehistoric suggests interaction between Central Texas and ceramic producing traditions in East and North Texas due to the presence of bone-tempered Leon Plain ceramics (Perttula et al. 1995). Other technological traits of this phase include the diagnostic Perdiz point and alternately beveled bifaces (Ricklis 1992).

\section{Historic Period}

The Historic period is characterized by European contact with Native cultures in the Americas. While Spanish explorations into Texas commenced in the 1500 s, European settlements, Spanish in particular, did not became part of the Texas landscape until the late 1600s. Mission settlements were first established in Bexar County in 1718 with Mission San Antonio de Valero (Chapa 1997).

\section{Previous Archaeological Investigations}

Archaeological sites are ubiquitous in the environs of the Salado Creek. They include: 41BX949, 41BX959, 41BX841, 41BX229, 41BX1007, 41BX17, 41BX271, 41BX1765 and 41BX1766.

41BX949 was recorded by Frank Weir in 1991 (THC 2008). The site was investigated during a larger testing project of five sites along Wurzbach Parkway. It was found to have shallow deposits of artifacts in secondary contexts. The site was considered ineligible for nomination to the NRHP (Potter and Black 1995).

41BX959 is located along the east bank of Mudd Creek. When the site was originally recorded in 1991 by C. K. Chandler, it consisted of tested cobbles, burned rock, lithic debitage and tools. Much of the area had been cleared of vegetation (THC 2008). The site was revisited and shovel tested in 2005 by CAR as part of a project for the San Antonio International Airport (Figueroa and Thompson 2005). The site has been heavily disturbed by landscape modifications and clearing. The 2005 airport survey not only revealed the site to be much larger than originally recorded, but it also revealed a historic component. Along with the recovery of historic artifacts (ceramics and glass), the remnants of a building that appears on the 1953 Longhorn, TX 7.5 USGS quadrangle map, were also identified. Cultural material scattered on the surface of the site and recovered from the upper deposits of shovel tests included cores, bifaces and flakes. Due to the extensive disturbance of the deposits and the lack of features, the site did not warrant formal designation as a SAL and was not recommended as eligible for nomination to the NRHP.

41BX841, located north of Loop 410 on the Lady Bird Johnson Park, was recorded by M. Kohnitz and identified as a lithic scatter. During the initial recording of the site no subsurface testing was conducted. No recommendations as to NRHP eligibility status were noted (THC 2008). The site was revisited during the Phase II survey (Figueroa 2008) and three shovel tests were excavated. Only one of the three tests was positive for cultural material. Cultural material recovered included burned rock and lithic debitage.

41BX229 (St. Mary's Hall site) is situated on a colluvial slope of Salado Creek, approximately thirty-five meters east of the present channel. The site was recorded in 1974 by M. Kohnitz and T. Hester (THC 2008). No subsurface testing was conducted during its initial recording but cultural material observed on the surface included debitage, scattered burned rock, points, native ceramics, and a burned rock midden (THC 2008). The site was excavated in 1974 and 1975 by the Southern Texas Archaeological Association. Excavations revealed multiple components. Cultural material included an extensive burned rock midden with remains dating from the Middle Archaic through the Late Prehistoric (Hester 1977). Below the midden ( $60-75 \mathrm{cmbs}$ ) was evidence of a Paleoindian component. In 1977, a University of Texas at San Antonio archaeology field school resumed the excavations exposing two large areas where Paleoindian material had been found. Late Paleoindian artifacts were found $60-75 \mathrm{cmbs}$ on top of a gravel lens. According to the geomorphologists that worked 
at the site, the late Paleoindian materials (Golondrina and Angostura points) were in situ (Hester 1977).

Site 41BX1007 was recorded in 1994 by C. K. Chandler and is located immediately west of Salado Creek. The site consists of a Late Prehistoric occupation that contains a midden, burned rock, Scallorn points and one triangular point. No subsurface testing was conducted but the depth of cultural deposits was estimated to be as much as one meter. No recommendations as to NRHP eligibility status were noted (THC 2008).

The proximity of two sites 41BX17 and 41BX271 and a more accurate plotting of 41BX17 indicate that both are part of a prehistoric site once located on a small knoll overlooking the east bank of Salado Creek (Thompson 2006). The western margin of the site known as $41 \mathrm{BX} 17$ originally extended at least $50 \mathrm{ft}$. into the highway right-of-way (ROW) where Harvey Kohnitz first identified it in the early 1960s. The majority of the site appears to extend for an unknown distance southward and beyond the ROW into property recently purchased by the City of San Antonio (Córdova et al. 2005).

Site 41BX17 has undergone several excavations. Archaeological investigations suggest the occupation of the site spans from about 4000 B.C. to A.D. 1200 as evidenced by the styles of projectile points uncovered during early excavations (Córdova et al. 2005; Thompson 2006; Schuetz 1966). The University of Texas at San Antonio conducted archaeological significance testing at 41BX17 from January to March 2006 (Thompson 2006). The distribution of the artifacts, the geomorphic investigations, the radiocarbon assays, and temporally diagnostic artifacts indicate the presence of Middle and Late Archaic archaeological materials with good stratigraphic integrity. Radiocarbon dates and preliminary artifact analysis suggests that prehistoric human occupation at the Granberg Site spanned 3000 years from the Middle Archaic to the Late Archaic (Thompson 2006).

41BX1765 is located just north of Loop 410, east of the Salado Creek within the floodplain. The site was identified during the survey of the Salado Creek Greenway from Wetmore to Loop 410 (Figueroa 2008). The area has been impacted by the construction of several structures, a paved road and parking lots associated with the Los Patios retail complex. Shovel testing in the area revealed a high density of alluvial gravels that represent localized flooding events. The site was defined by two positive shovel tests that contained debitage $(n=1)$ and the base of an unidentifiable projectile point. Both lithics contained evidence of stream rolling and the projectile point base was heavily patinated. The cultural material recovered at the site appeared to be in secondary context and lacked integrity. Further work was not recommended at the site. The
CAR recommended that the site was not eligible for NRHP nomination.

Site 41BX1766 is located west of Salado Creek within the floodplain. The site was identified during the survey of the Salado Creek Greenway from Wetmore to Loop 410 (Figueroa 2008). The surface of the site is covered by gravels, associated with high energy flooding events. The site was defined by three shovel tests, one positive and two negative. The positive test contained a mixture of modern and prehistoric materials. Level $2(10-20 \mathrm{cmbs})$ contained glass $(\mathrm{n}=63)$. Metal $(\mathrm{n}=1)$, debitage $(\mathrm{n}=1)$ and burned rock $(\mathrm{n}=1)$ were present in Level 3. Level 4 contained debitage $(n=5)$ and Level 5 contained debitage $(n=1)$, burned rock $(n=2)$ and road tar $(n=1)$. The final level of the shovel test, Level 6, contained glass $(\mathrm{n}=1)$, burned rock $(n=2)$, debitage $(n=5)$, plaster $(n=1)$ and faunal material $(n=1)$. A wooden post spanned the shovel test from Level 3 to its terminal depth $(60 \mathrm{cmbs})$. It was evident from the mixture of cultural material and the high density of gravels that the deposits were in a secondary context. Further work was not recommended at 41BX1766 and the site was not recommended as eligible for listing on the NRHP.

\section{Previous work at 41BX1764}

During the initial discovery of 41BX1764, in February 2008 (Figueroa 2008), surface visibility was low (10\%) and no artifacts were observed on the ground surface. Thirteen shovel tests were excavated to determine the vertical and horizontal extent of the cultural material. Shovel tests excavated along the central axis of the site revealed dark brown silty clay. Those excavated on the western fringes contained heavy gravels $(<50 \%)$ in the first three levels followed by a sterile, dark brown, silty clay. Five of the shovel tests were positive for cultural material. Debitage was the predominant material recovered from the site $(\mathrm{n}=22)$, followed by burned rock $(\mathrm{n}=3)$. A Perdiz projectile point was recovered from Level 2 (10-20 cmbs). The greatest amount of material was present in Level $1(\mathrm{n}=12)$, gradually decreasing in the lower levels. There was a second peak of material in Level $6(n=4)$.

The Perdiz projectile point identified in Level 2 clearly indicates a Late Prehistoric component. Furthermore, the vertical distribution of artifacts suggests a second component in Level $6(50-60 \mathrm{cmbs})$. The CAR recommended that 41BX1764 is potentially eligible for listing in the National Register of Historic Places. The site was in jeopardy of secondary impacts associated with the proposed Greenway trail construction. The CAR recommended that the proposed trail corridor be relocated or that eligibility testing be conducted on the site (Figueroa 2008). The trail design team in conjunction with the San Antonio Parks and Recreation 
Department determined that the preferred location of the proposed trail is through the site. This decision was communicated to the Texas Historical Commission who concurred with the recommendation to initiate testing. 


\section{Chapter 3: Field and Laboratory Methods}

\section{Field Methods}

Testing methods implemented during the field project consisted of seven hand-excavated 1-x-1 m test units. The purpose of the excavation units was to search for features and to determine the horizontal and vertical distribution of artifacts. A $100 \mathrm{~m}-\mathrm{x}-50 \mathrm{~m}$ grid was established over the site.

Each unit was assigned a northing and easting designation and a test unit number. Datums were established within 10 $\mathrm{cm}$ of each test unit and set $10 \mathrm{~cm}$ above ground surface. The units were excavated in $10-\mathrm{cm}$ levels and screened through $1 / 4$ " hardware cloth. The depths of the test units varied and were based on the results of shovel tests excavated during the previous pedestrian survey (Figueroa 2008).

All cultural material was collected and bagged by level. Appropriate unit level forms were maintained for each unit. The project archaeologist inspected the walls of the excavated units. Selected walls were profiled and appropriate notes and digital photographs were taken. All artifacts encountered and samples recovered were taken to CAR for processing and analysis.

\section{Laboratory Methods}

All archaeological materials recovered during testing were fully analyzed, described, and reported. All cultural material and records collected and/or generated during the archaeological testing were prepared in accordance with federal regulation 36 CFR part 79, and in accordance with current guidelines of the Center for Archaeological Research. Artifacts processed in the CAR laboratory were washed, airdried, and stored in archival-quality bags. Artifacts were sorted into appropriate analytical categories. Acid-free labels were placed in all artifact bags. Each label displayed provenience information and a corresponding lot number laser printed or written in pencil. Tools were labeled with permanent ink over a clear coat of acrylic and covered by another acrylic coat. In addition, a small sample of unmodified debitage from each lot was labeled with the appropriate provenience data. Artifacts were separated by class and stored in acid-free boxes identified with standard labels. The data was entered into a Microsoft Access database. All artifacts were permanently curated at CAR.

Field notes, forms, and hard copies of photographs were placed in labeled archival folders. All field forms were completed in pencil. Documents and forms were printed on acid-free paper and any soiled forms were placed in archivalquality page protectors. A copy of the final report in Adobe Acrobat ${ }^{\circledR}$ file format and all digital material pertaining to the project, including photographs, were placed onto a $\mathrm{CD}$ and permanently curated with the field notes and documents at the Center for Archaeological Research.

The collected burned rock was processed and quantified in the CAR laboratory. In consultation with the THC the burned rock, which possessed little scientific value, was discarded pursuant to Chapter 26.27 (g) (2) of the Antiquities Code of Texas. 



\section{Chapter 4: Results of Archaeological Investigations}

During August of 2008 NRHP eligibility testing of 41BX1764 (the Dos Mujures site) was conducted. Seven 1-x-1 m units were excavated during the archaeological investigations (Figure 4-1). This chapter discusses the results of the testing of 41BX1764. Although no features were encountered, two components were identified on the site. One component was dated to the Late Prehistoric Toyah Phase based on the identification of a beveled knife encountered during testing

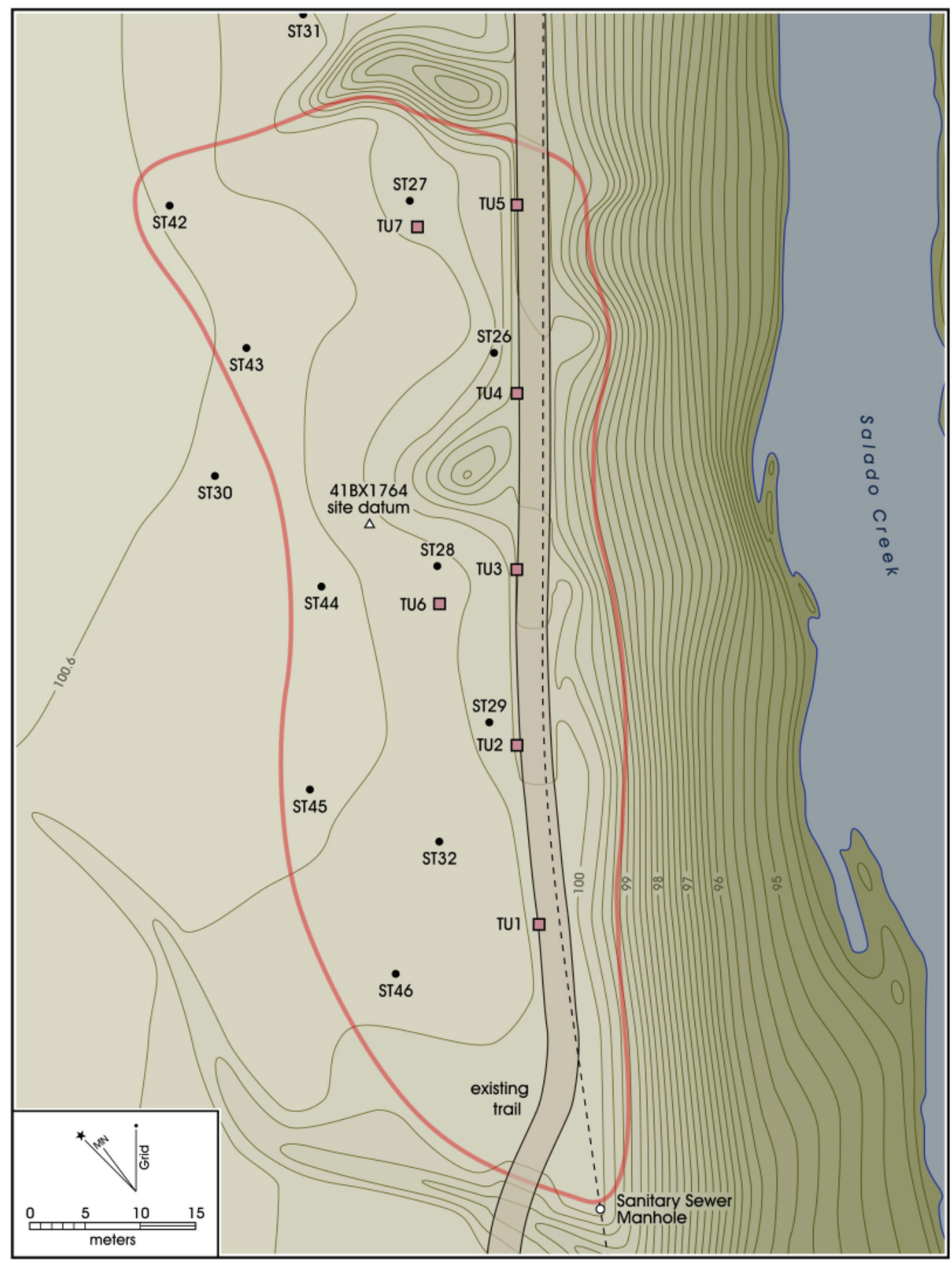

Figure 4-1. Site map of 41BX1764 showing test units, Phase I shovel tests, and other impacts to the site. 
and Perdiz point recovered during survey (Figueroa 2008). The temporal affiliation of the deeper component is not known.

\section{Test Units}

Test units were excavated in $10 \mathrm{~cm}$ levels and given a number along with a northing and easting coordinate. Test Unit 1 (N35/E201) was excavated to $60 \mathrm{~cm}$ below surface (cmbs). Test Units 2 (N51/E199), 3 (N67/E199) and 6 (N64/E192) were excavated to one meter below surface. Test Unit 4 (N88/E199) excavations terminated at $40 \mathrm{cmbs}$. Test Unit 5 (N100/E199) and Test Unit 7 (E97/E191) were excavated to $50 \mathrm{cmbs}$. The amount of soil excavated from the seven test units totaled $5 \mathrm{~m}^{3}$. There were a total of 617 artifacts recovered from the test units. Table 4-1 presents the cultural material recovered from the seven test units. No features were encountered during testing. Burned rock was scattered throughout the units but was never distinguished as concentrations or features. TUs 1 through 5 were located on the trail and were lower in elevation than TUs 6 and 7. Elevations differences varied from 20 to $60 \mathrm{~cm}$.

\section{Test Unit 1 (N35/201)}

Test Unit 1 (N35/E201) was located in the far southern portion of the site, situated on the existing trail (see Figure 4-1). The unit terminated at $70 \mathrm{~cm}$ below datum (cmbd) and was excavated in six 10-cm levels. Three stratigraphic zones

Table 4-1. Cultural Material Recovered from Test Units

\begin{tabular}{|c|c|c|c|c|c|c|c|c|}
\hline Test Unit & Level & ”Burned Rock & Debitage & Lithic Tools and Cores & Glass & Metal & Modern & Grand Total \\
\hline \multirow{6}{*}{1} & 1 & 0 & 0 & 0 & 0 & 0 & 0 & 0 \\
\hline & 2 & $5(35.8 \mathrm{~g})$ & 18 & 1 & 1 & 0 & 0 & 25 \\
\hline & 3 & $4(7.6 \mathrm{~g})$ & 5 & 0 & 1 & 2 & 0 & 12 \\
\hline & 4 & 0 & 6 & 1 & 0 & 0 & 0 & 7 \\
\hline & 5 & $3(6.8 \mathrm{~g})$ & 9 & 0 & 0 & 0 & 0 & 12 \\
\hline & 6 & 0 & 0 & 0 & 0 & 0 & 0 & 0 \\
\hline Total & & $12(50.2 \mathrm{~g})$ & 38 & 2 & 2 & 2 & 0 & 56 \\
\hline \multirow{10}{*}{2} & 1 & $4(4.7 \mathrm{~g})$ & 9 & 0 & 16 & 1 & 17 & 47 \\
\hline & 2 & $2(0.7 \mathrm{~g})$ & 6 & 0 & 1 & 0 & 0 & 9 \\
\hline & 3 & $10(26.5)$ & 7 & 1 & 4 & 1 & 2 & 25 \\
\hline & 4 & $3(0.5 \mathrm{~g})$ & 5 & 0 & 0 & 0 & 0 & 8 \\
\hline & 5 & $3(3.8 \mathrm{~g})$ & 12 & 0 & 0 & 0 & 0 & 15 \\
\hline & 6 & $1(0.2 g)$ & 9 & 0 & 0 & 0 & 0 & 10 \\
\hline & 7 & $2(0.6 \mathrm{~g})$ & 7 & 1 & 0 & 0 & 0 & 10 \\
\hline & 8 & $2(8.3 \mathrm{~g})$ & 1 & 0 & 0 & 0 & 0 & 3 \\
\hline & 9 & 0 & 2 & 0 & 0 & 0 & 0 & 2 \\
\hline & 10 & 0 & 4 & 1 & 0 & 0 & 0 & 5 \\
\hline Total & & $27(45.3 \mathrm{~g})$ & 62 & 3 & 21 & 2 & 19 & 134 \\
\hline \multirow{10}{*}{3} & 1 & 0 & 2 & 0 & 2 & 0 & 0 & 4 \\
\hline & 2 & $3(4.1 \mathrm{~g})$ & 4 & 0 & 3 & 0 & 0 & 10 \\
\hline & 3 & $4(11 \mathrm{~g})$ & 6 & 0 & 3 & 0 & 0 & 13 \\
\hline & 4 & $2(1.4 \mathrm{~g})$ & 12 & 0 & 1 & 0 & 0 & 15 \\
\hline & 5 & 0 & 4 & 0 & 0 & 0 & 0 & 4 \\
\hline & 6 & 0 & 3 & 0 & 0 & 0 & 0 & 3 \\
\hline & 7 & 0 & 1 & 0 & 0 & 0 & 0 & 1 \\
\hline & 8 & $4(236.7 \mathrm{~g})$ & 0 & 0 & 0 & 0 & 0 & 4 \\
\hline & 9 & $1(0.3 \mathrm{~g})$ & 0 & 0 & 0 & 0 & 0 & 1 \\
\hline & 10 & 0 & 0 & 0 & 0 & 0 & 0 & 0 \\
\hline Total & & $14(253.5 \mathrm{~g})$ & 32 & 0 & 9 & 0 & 0 & 55 \\
\hline \multirow{4}{*}{4} & 1 & 0 & 0 & 0 & 1 & 1 & 0 & 2 \\
\hline & 2 & 0 & 3 & 1 & 13 & 1 & 2 & 20 \\
\hline & 3 & $1(53.4 \mathrm{~g})$ & 6 & 0 & 2 & 0 & 0 & 9 \\
\hline & 4 & 0 & 0 & 0 & 0 & 0 & 0 & 0 \\
\hline Total & & $1(53.4 \mathrm{~g})$ & 9 & 1 & 16 & 2 & 2 & 31 \\
\hline
\end{tabular}


Table 4-1. Continued...

\begin{tabular}{|c|c|c|c|c|c|c|c|c|}
\hline Test Unit & Level & *Burned Rock & Debitage & Lithic Tools and Cores & Glass & Metal & Modern & Grand Total \\
\hline \multirow{5}{*}{5} & 1 & 0 & 0 & 0 & 0 & 0 & 0 & 0 \\
\hline & 2 & 0 & 3 & 0 & 0 & 0 & 0 & 3 \\
\hline & 3 & $1(0.5 g)$ & 5 & 0 & 0 & 0 & 0 & 6 \\
\hline & 4 & $1(0.8 g)$ & 2 & 0 & 0 & 0 & 0 & 3 \\
\hline & 5 & 0 & 1 & 0 & 0 & 0 & 0 & 1 \\
\hline Total & & $2(1.3 \mathrm{~g})$ & 11 & 0 & 0 & 0 & 0 & 13 \\
\hline \multirow{10}{*}{6} & 1 & $1(1.7 g)$ & 18 & 0 & 0 & 0 & 0 & 19 \\
\hline & 2 & $4(29.9)$ & 22 & 0 & 0 & 0 & 0 & 26 \\
\hline & 3 & $6(49.7 g)$ & 25 & 0 & 0 & 0 & 0 & 31 \\
\hline & 4 & $11(58.3 g)$ & 45 & 0 & 0 & 0 & 0 & 56 \\
\hline & 5 & $3(11.8 \mathrm{~g})$ & 15 & 0 & 0 & 0 & 0 & 18 \\
\hline & 6 & $4(6.3 g)$ & 11 & 0 & 1 & 0 & 0 & 16 \\
\hline & 7 & $4(13.8 \mathrm{~g})$ & 14 & 0 & 0 & 0 & 0 & 18 \\
\hline & 8 & $7(8.1 \mathrm{~g})$ & 23 & 0 & 0 & 0 & 0 & 30 \\
\hline & 9 & $4(31.9 g)$ & 4 & 2 & 0 & 0 & 0 & 10 \\
\hline & 10 & 0 & 8 & 0 & 0 & 0 & 0 & 8 \\
\hline Total & & $44(211.5 \mathrm{~g})$ & 185 & 2 & 1 & 0 & 0 & 232 \\
\hline \multirow{5}{*}{7} & 1 & $25(41.2 \mathrm{~g})$ & 32 & 0 & 0 & 0 & 0 & 57 \\
\hline & 2 & $9(10.2 \mathrm{~g})$ & 14 & 0 & 0 & 0 & 0 & 23 \\
\hline & 3 & $5(82.4 \mathrm{~g})$ & 5 & 1 & 0 & 0 & 0 & 11 \\
\hline & 4 & $3(61.7 \mathrm{~g})$ & 0 & 0 & 0 & 0 & 0 & 3 \\
\hline & 5 & $1(1.2 \mathrm{~g})$ & 0 & 1 & 0 & 0 & 0 & 2 \\
\hline Total & & $43(196.7)$ & 51 & 2 & 0 & 0 & 0 & 96 \\
\hline $\begin{array}{l}\text { Grand } \\
\text { Total }\end{array}$ & & $143(811.9 \mathrm{~g})$ & 388 & 10 & 49 & 6 & 21 & 617 \\
\hline
\end{tabular}

* counts and weights (in grams) given.

were distinguished in this unit (Figure 4-2). Zone 1 consisted of a yellowish brown (10YR 5/4) sandy clay that contained $>50 \%$ gravels. This zone appears to represent fill that was installed for the existing trail. Zone 1 encompassed Levels $1(10-20 \mathrm{cmbd})$. In Zone 2, the matrix changed to a very dark gray (10YR 3/1) silty clay with a drastic decrease in gravels. Zone 2 was associated with Levels 2, 3, and 4 (20$50 \mathrm{cmbd}$ ). The matrix in Zone 3 remained silty clay but the color changed to brown (10 YR 4/3). This zone was visible in Levels 5 and 6 (60 to $70 \mathrm{cmbd}$ ).

Excavations of this unit produced 56 artifacts (see Table 4-1). The majority of artifacts consisted of lithic debitage $(n=38)$. Level 1 contained most of the material (45\%) including debitage $(\mathrm{n}=18)$, burned rock $(\mathrm{n}=5 ; 35.8 \mathrm{~g})$ and a lithic core $(\mathrm{n}=1)$. Debitage and burned rock were present through Level 5 but in lower frequencies than in Level 1. A fragment of a beveled knife was recovered from Level 4 (see Chapter 5).

\section{Test Unit 2 (N51/E199)}

Test Unit 2 (N51/E199) was located 16 meters northeast of Test Unit 1. Four stratigrapic zones were identified in this unit (Figure 4-3). Zone 1 was light yellowish brown sandy

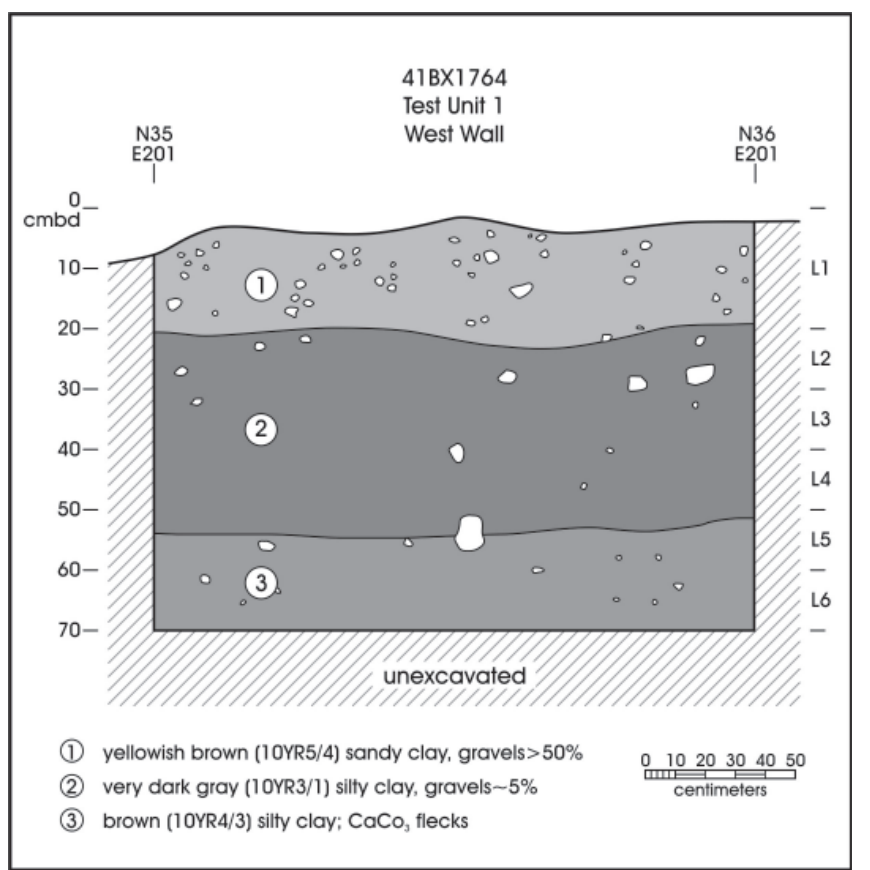

Figure 4-2. Profile of the west wall of Test Unit 1.

clay (10 YR 6/4) with $20 \%$ gravels. As seen in Test Unit 1, the upper zone is associated with trail fill. This zone was 
five centimeters thick and was seen in Level 1. Zone 2 was a brown (10YR 4/3) silty clay soil that spanned from Level 1 to 5 (15 to $50 \mathrm{cmbd}$ ). Zone 3 consisted of a dark yellowish brown (10 YR 4/6) sandy clay with an increase in gravels $(30 \%)$ that spanned from the end of Level 5 to Level 7 (80 cmbd). In Zone 4, gravels increased drastically (60\%) and the soil remained a yellowish brown (10 YR 5/6) sandy clay. This zone was seen in Levels 8, 9, and 10.

A total of 134 artifacts were recovered from Test Unit 2 (Table 4-1). Although the majority of the artifacts were concentrated in Level 1, 72\% of the artifacts from this level consisted of modern materials. Level 3 contained the highest amount of prehistoric material consisting of debitage $(n=7)$, burned rock $(\mathrm{n}=10 ; 26.5 \mathrm{~g})$ and one biface. Three pieces of debitage from Levels 6 and 7 show characteristics of smoothing associated with river rolling. Cultural materials began to decrease below Level 7. Bifaces were recovered from Levels 3, 7 and 10.

\section{Test Unit 3 (N67/E199)}

Test Unit 3 (N67/E199) was 16 meters northeast of Test Unit 2. This unit was excavated to a depth of $110 \mathrm{cmbd}$. Five soil horizons were identified in this unit (Figure 4-4). Zone 1 was a dark grayish brown (10YR 4/2) silty soil and was present in Level 1. Zone 2 soil was a very dark gray (10 YR 3/1) silty clay and was found in Level 2. Zone 3 was a brown (10 YR $4 / 3$ ) silty clay with an increase of gravel towards the bottom of the zone. Zone 3 was present in Levels 3 and 4. Zone 4, situated in Levels 5, 6, 7 and the upper reaches of Level 8, consisted of dark yellowish brown (10 YR 4/4) silt with a high density of gravels and cobbles $(80 \%)$. This zone represents high energy flood deposition. The final zone encountered in the test unit, Zone 5, contained a dark yellowish brown sandy clay with slightly decreasing gravels and was present in Levels 8, 9 and 10.

Fifty-five artifacts were recovered from this test unit. Level 4 contained the highest amount of prehistoric material $(n=14)$ for the unit. There was decrease in materials below Level 4 but there was a small increase in Level $8(n=4)$. However, the lower levels of the unit were dominated by heavy gravels and one debitage specimen exhibited evidence of stream rolling.

\section{Test Unit 4 (N88/E199)}

Test Unit 4 (N88/E199) was excavated to a depth of $50 \mathrm{cmbd}$ in four $10-\mathrm{cm}$ levels. The unit was located 21 meters northeast of Test Unit 3. A small ephemeral drainage is immediately south west of the test unit (see Figure 4-1), exposing the area to runoff and subsequently to erosion. Two stratagraphic zones were identified in the unit (Figure 4-5). Zone 1 was comprised of a very dark grayish brown (10YR 3/2) silty

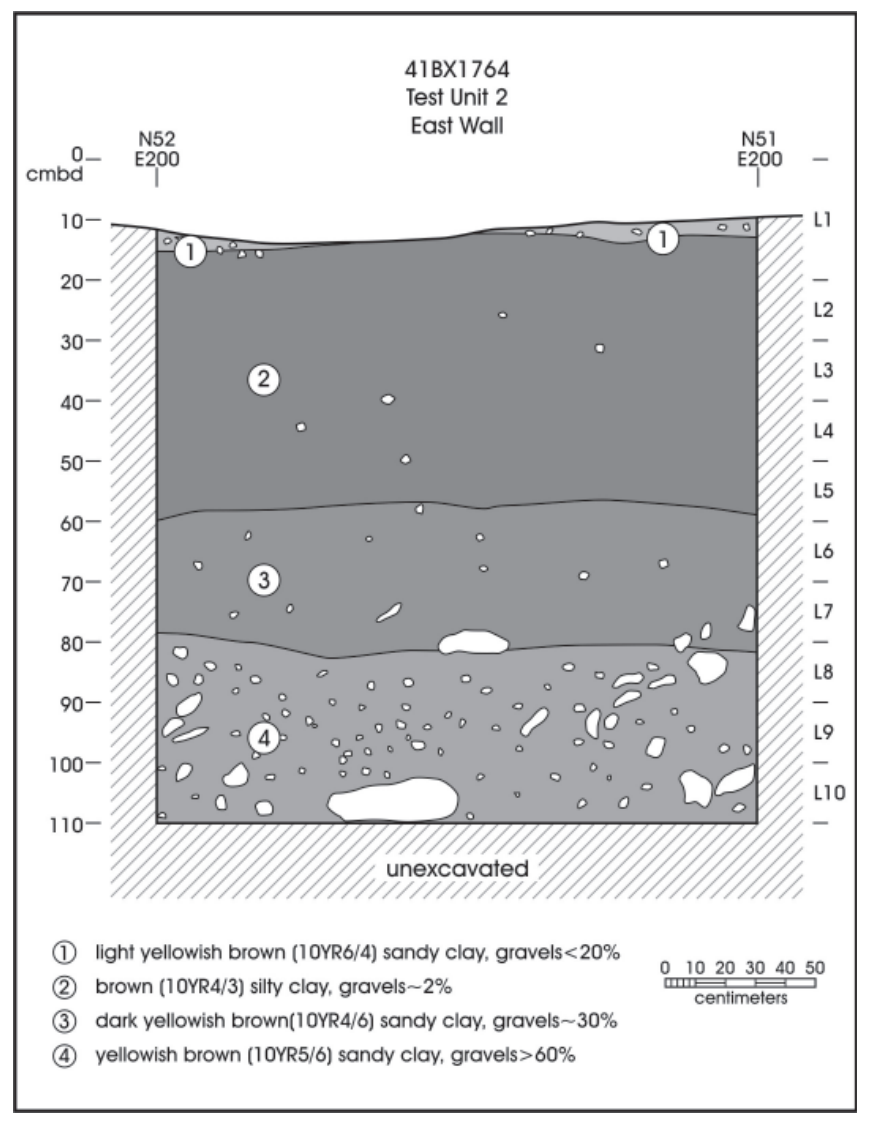

Figure 4-3. Profile of the east wall of Test Unit 2.

clay. This Zone was associated with Levels 1, 2 and 3. Zone 2 , present in the lower portions of Level 3 and the entirety of Level 4, contained a dark yellowish brown (10 YR 4/6) silty clay, heavily compacted, with the presence of calcium carbonates.

A total of 31 artifacts were recovered from this unit. Artifacts from this unit were only present in the first three levels (within Zone 1). Level 2 contained debitage $(n=3)$, one edge-modified flake and modern glass. Level 3 produced the highest percentage of prehistoric artifacts $(64 \%)$ in the unit. Level 4 was void of cultural material.

\section{Test Unit 5 (N100/E199)}

Test Unit 5 was located on the far northeastern margin of the site (see Figure 4-1) 12 meters northeast of Test Unit 6. This unit exhibited four stratigraphic zones (Figure 4-6). Zone 1 was a loose sandy loam that was light yellowish brown (10 YR 64) with $>30 \%$ gravels. Zone 2 also contained a loose matrix but was very dark grayish brown silty clay. Zones 1 and 2 appeared to be colluvial in nature and eroding down slope. Zone 3 consisted of a very dark grayish brown (10 YR 3/2) silty clay. Zone 4 was visible mostly in the northern 


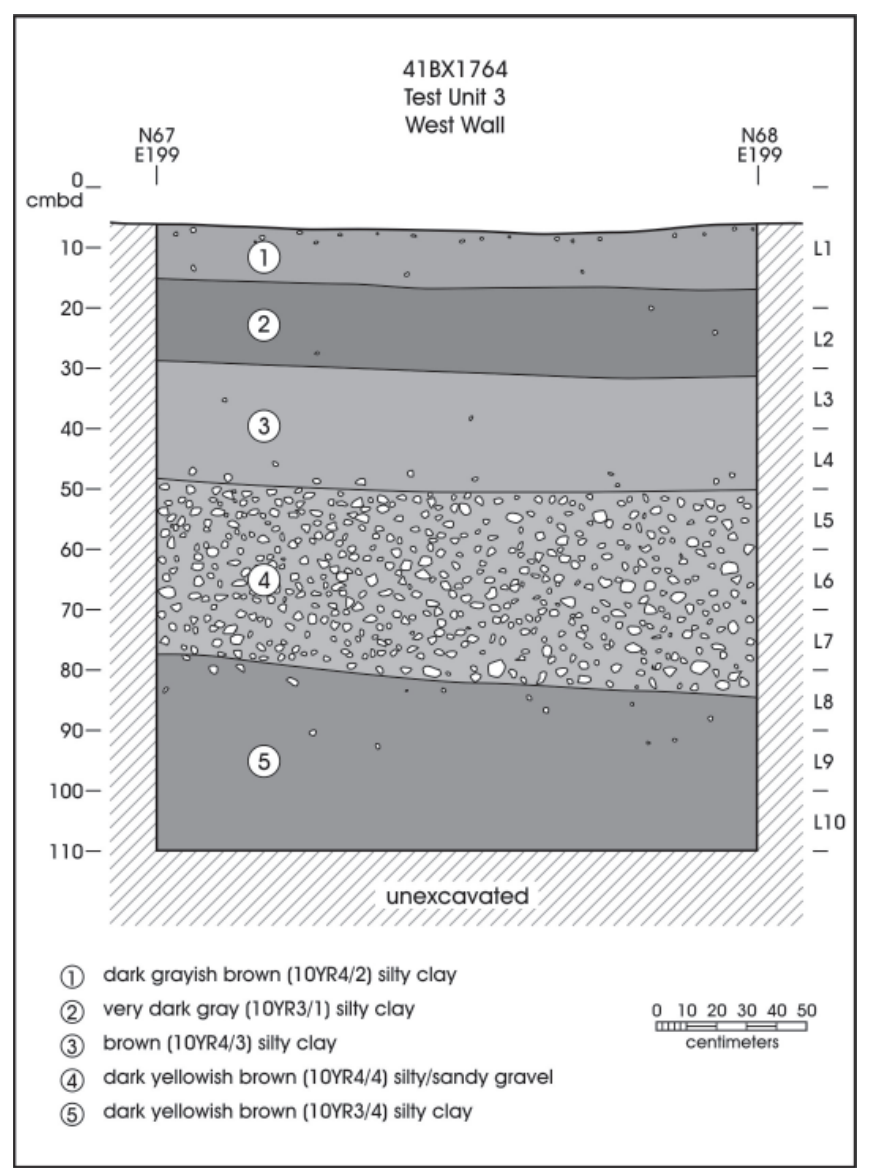

Figure 4-4. Profile of the west wall of Test Unit 3.

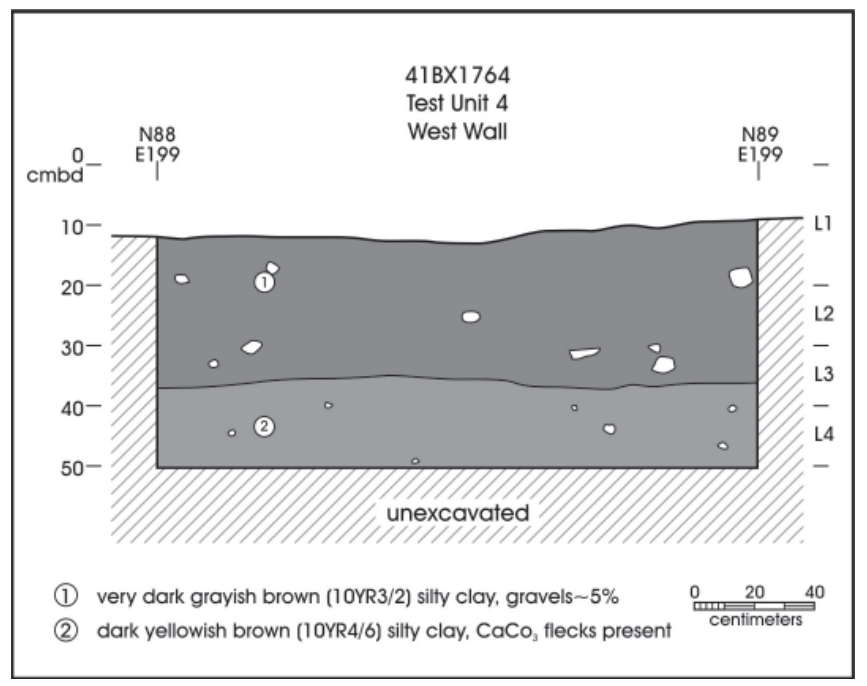

Figure 4-5. Profile of the west all of Test Unit 4.

portion of the unit and was a dark yellowish brown (10 YR 4/6) silty clay with flecks of calcium carbonates.

In the eastern portion of the test unit, Zone 1 comprised Levels 1, 2, and half of Level 3. In the western portion of the

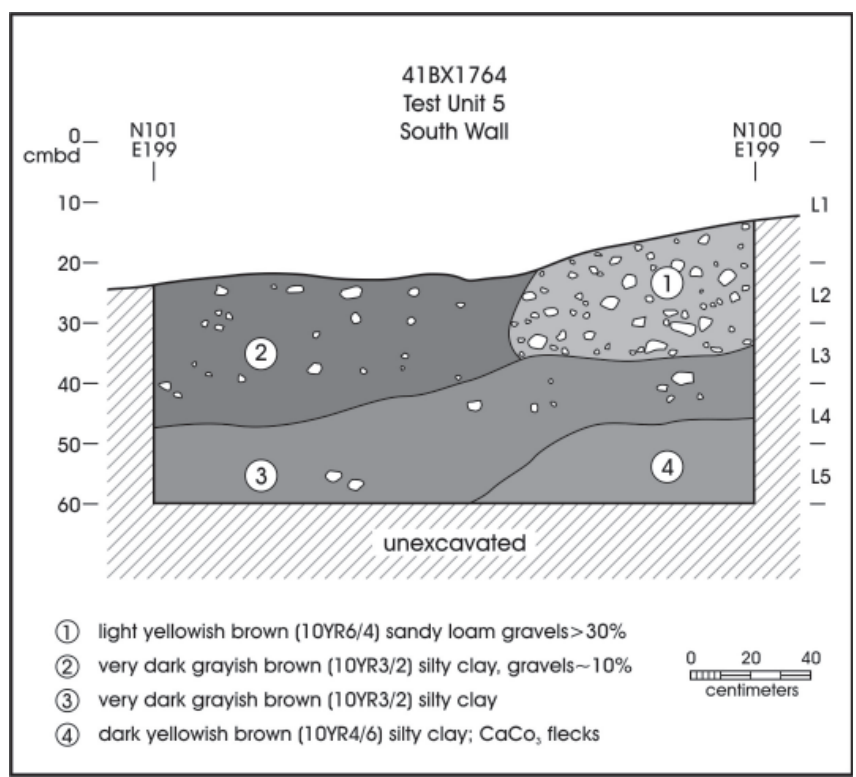

Figure 4-6. Profile of the south wall of Test Unit 5.

unit Zone 2 was seen in Levels 2, 3 and 4. Zone 3 extended from Level 3 in the western portion of the unit and to Level 5 in the eastern portion of the unit.

Test Unit 5 produced a small amount of artifacts (Table 4-1; $\mathrm{n}=13$ ). Level 3 contained the highest amount of artifacts in the unit $(n=6)$. The final level of the unit contained a single piece of debitage.

\section{Test Unit 6 (N64/E192)}

Test Unit 6 was located to the west of the trail, seven meters northwest from Test Unit 3 (see Figure 4-1). The unit terminated at $100 \mathrm{cmbd}$ and was excavated in $10(10-\mathrm{cm})$ levels. Four stratagraphic zones were identified in this unit (Figure 4-7). Zone 1, found in Levels 1, 2, and 3, was very dark grayish brown silty loam. In Zone 2 the matrix changed to a very dark gray silty clay and was present in Levels 4 and 5 . Zone 3 consisted of brown silty clay and was situated in Levels 6 and 7. Zone 4, seen in Levels 8, 9 and 10, was made up of dark yellowish brown silty clay with a high percentage of gravels $(75 \%)$.

This test unit had the highest frequency of artifacts $(n=232$; see Table 4-1). The majority of artifacts were from Level 4 including 45 pieces of debitage. The artifact count gradually decreased below Level 4 but increased again in Level 8 with 30 artifacts. One piece of debitage from Level 8 showed evidence of river rolling. Two lithic tools, a retouched flake and a biface, were recovered from Level 9. 


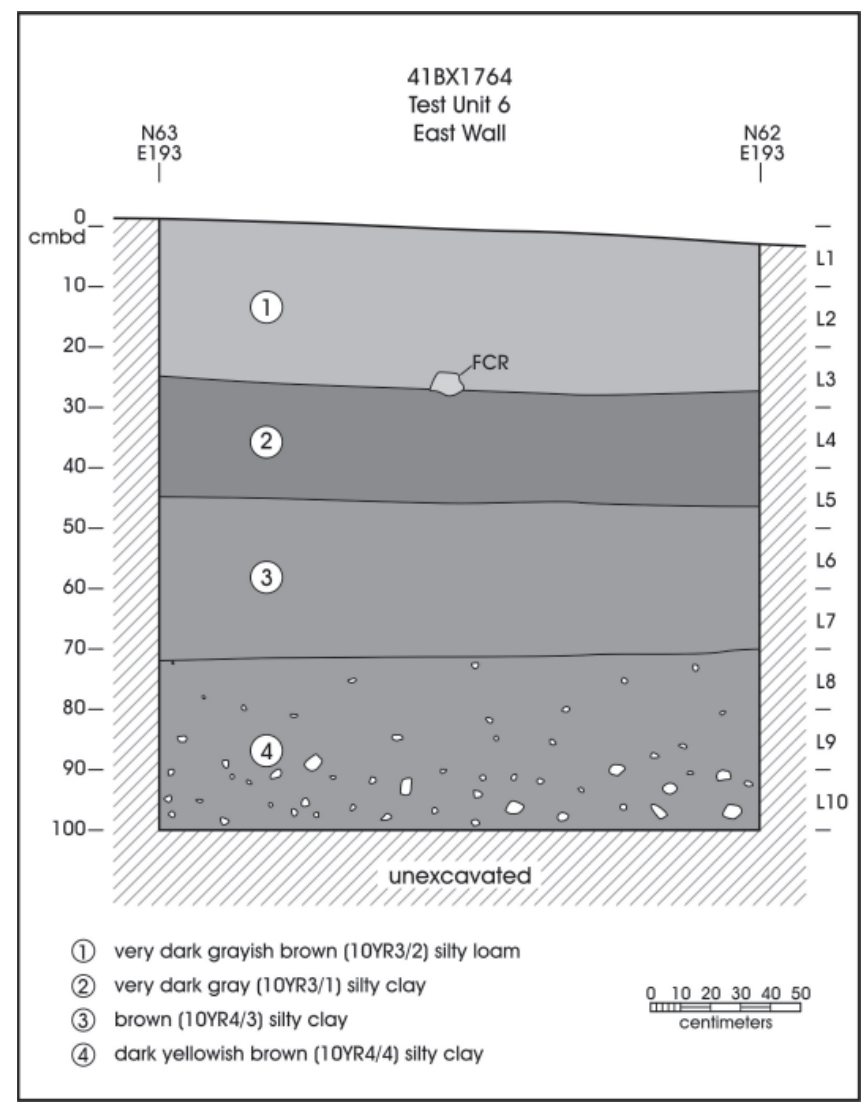

Figure 4-7. Profile of east wall of Test Unit 6.

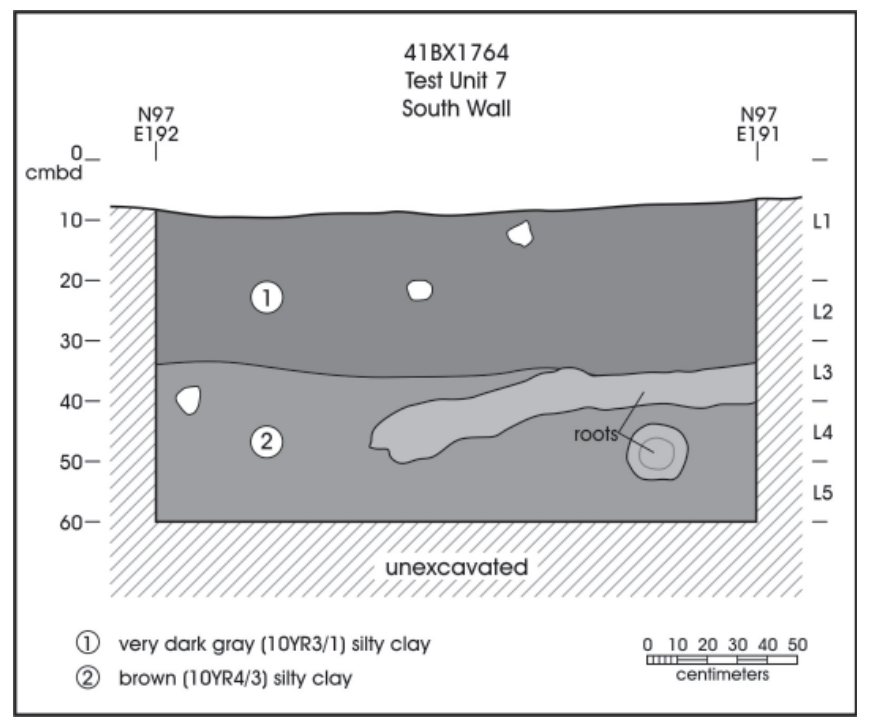

Figure 4-8. Profile of south wall of Test Unit 7.

six centimeters in diameter, dominated a majority of Levels 4 and 5 and could account for the lack of artifacts in these levels (Figure 4-9).

\section{Summary}

The central axis of the site appeared to contain the most intact deposits, while the eastern portion of the site was disturbed by the trail installation and erosion associated with a drainge. The test units located on the existing trail varied in artifact

\section{Test Unit 7 (N97/E191)}

Test Unit 7 was located eight meters west of Test Unit 5 (see Figure 4-1). This unit was excavated to a depth of $60 \mathrm{cmbd}$ in five $10-\mathrm{cm}$ levels. Only two zones were apparent in Test Unit 7 (Figure 4-8). Zone 1, contained very dark gray silty clay with a small amount of gravels and roots. Levels 1, 2 and the upper portion of Level 3 were associated with Zone 1. The matrix that made up Zone 2 was brown (10 YR 4/3) silty clay containing large roots. The remaining excavated levels were associated with Zone 2.

The unit produced 96 artifacts. The majority of artifacts (83\%) from this test unit were encountered in Levels 1 and 2 and consisted of debitage and burned rock (see Table 4-1). An edge modified flake was recovered from Level 3, while a core was found in Level 5. Large roots, measuring five to

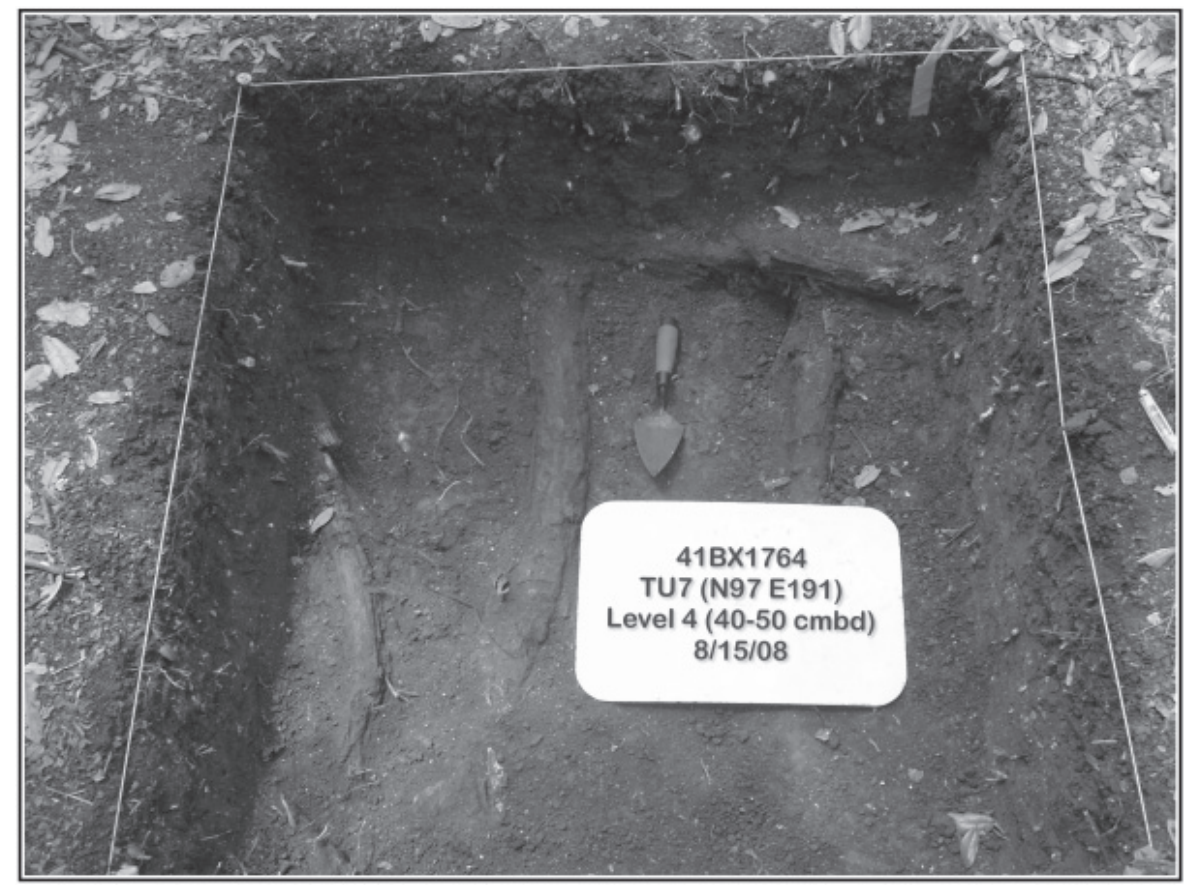

Figure 4-9. Plan view of Test Unit 7, Level 4, note large roots. 
densities. Test Units 1 and 2, on the southern portion of the trail, contained higher artifact densities (Test Unit 1, 93 artifacts per $\mathrm{m}^{3}$; Test Unit 2, 134 artifacts per $\mathrm{m}^{3}$ ) than units on the northern potion of the trail (Test Unit 3, 55 artifacts per $\mathrm{m}^{3}$; Test Unit 4, 78 artifacts per $\mathrm{m}^{3}$; Test Unit 5, 26 artifacts per $\mathrm{m}^{3}$ ). The highest artifact density was located off the existing trail. Test Unit 6 west of Test Unit 3, contained 232 artifacts per $\mathrm{m}^{3}$. Although Test Unit 7 was located in the northern portion of the site, it contained a higher density of artifacts (192 artifacts per $\mathrm{m}^{3}$ ) than Test Units 4 and 5.
Of the ten lithic tools encountered during testing, only one was diagnostic. A beveled knife was encountered in Test Unit 1 in Level 4. Both the beveled knife and the Perdiz projectile point encountered during shovel testing (ST 26, Level 2) are diagnostics associated with the Toyah Phase of the Late Prehistoric period (Hester 1995:444-445). The three units excavated to one meter below surface (Test Units 2, 3 , and 6) all point to a decrease in the density of chipped stone and burned rock below Level 5 (Figure 4-10). The diagnostics and artifact densities suggest that Levels 1-5

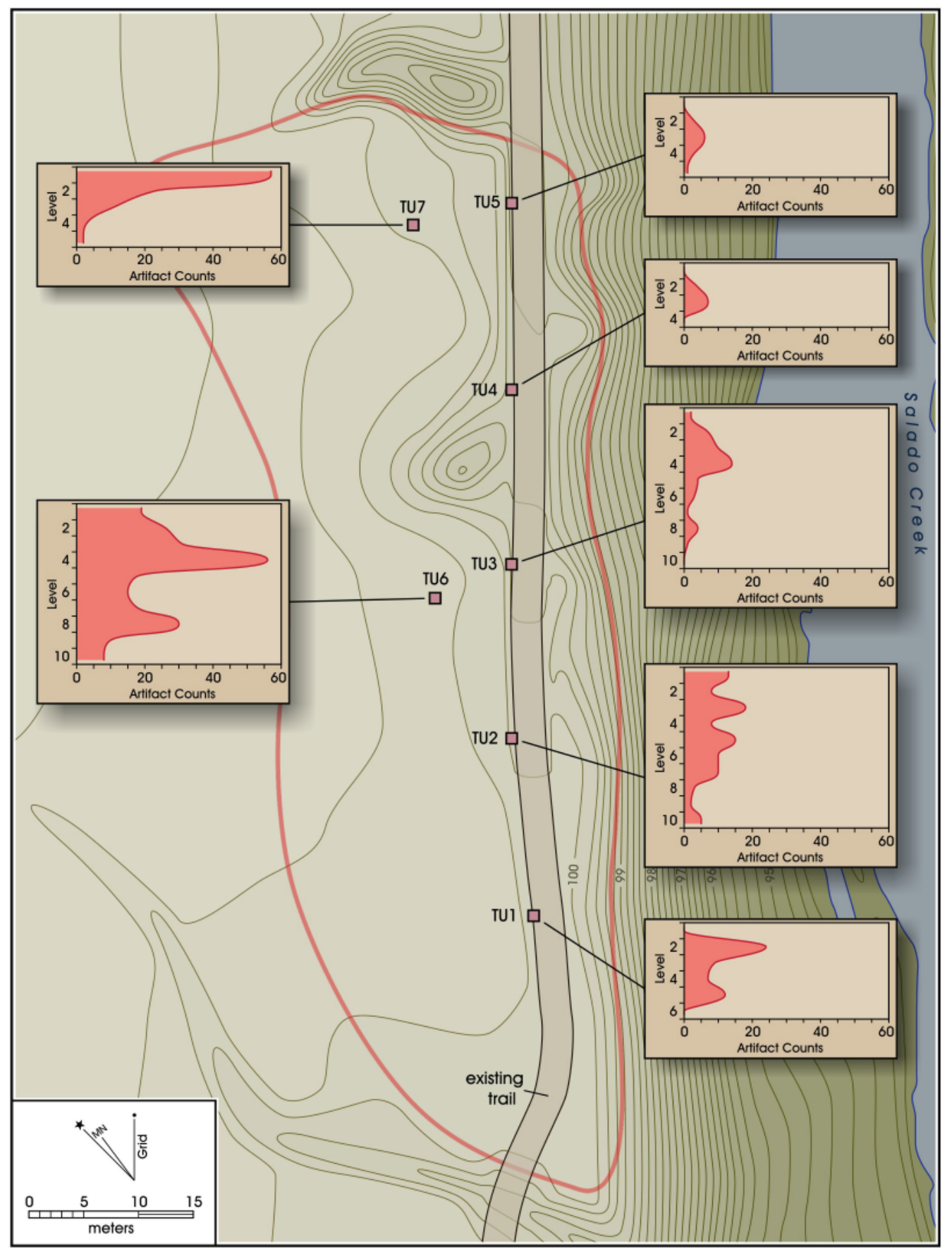

Figure 4-10. Site map of 41BX1764 with bar chart showing prehistoric artifact counts per test unit. 
represent a Toyah Phase component, while the lower levels (6-10) represent a separate and older component. The Toyah component occurs within three identified strata that consist of dark brown to dark grayish brown clay. Although the context of the Toyah deposits appears to be primary, the presence of river rolled debitage and modern trash point to a high degree of disturbance likely due to the site's proximity to the three drainages. The strata in the lower component contain a high percentage of gravels which are associated with high energy deposition and artifacts in a secondary context, specifically river rolled debitage. Sterile soils were encountered in Test Unit 4 in Level 4. The unit was likely exposed to heavy soil erosion given its proximity to a drainage. 


\section{Chapter 5: Lithic Analysis}

Prehistoric materials recovered from the test unit excavations include burned rock and chipped lithics. The lithic material consists of tools and debitage. The lithic analysis includes material from all test units. The purpose of the analysis is to discern any technological or temporal patterning that might be present in test units. If the upper five levels of the site represent a Toyah Phase component then this should be reflected in the patterning of lithic material.

\section{Debitage Patterns}

The majority of the cultural material recovered from testing was debitage (63\%). Three hundred and eighty eight pieces of debitage were analyzed. Attributes that were recorded for each specimen during the analysis included cortex percentage, maximum dimension, flake completeness and patina (presence or absence).

\section{Cortex}

The amount of cortex on a piece of debitage is typically used to determine reduction processes (Andrefsky 1998). Lithic tool manufacture should result in late reduction debitage containing less cortex than early reduction pieces. Of course, raw material size could also be a factor in the amount of cortex. Debitage produced from cobbles with complete cortical surfaces will produce flakes with a greater amount of dorsal cortex (Andrefsky 1989: 109). Magne (1989) notes that if raw material is not easily available, there will be noticeable variability in the reduction stage processes. High amounts of cortex will be typically found with pebble-based material. Research (Mauldin and Figueroa 2005) has shown that areas of high raw material availability will have a higher percentage of tertiary flakes.

For this part of the analysis the percentage of cortex was determined for each piece of debitage. A specimen was noted as having $0 \%, 1-50 \%$, or $51-100 \%$. An examination of the specimens from all test units resulted in $85 \%$ of the specimens with $0 \%$ cortex, $11 \%$ of the specimens with $1-50 \%$ cortex and $4 \%$ of the specimens with $51-100 \%$ cortex. Comparing cortex percentage by component shows similar patterns and no distinctions can been observed between the two components (Table 5-1). Based on data identified by Mauldin and Figueroa (2005:83-87), the percentage (85\%) of tertiary flakes at 41BX1764 appears to correlate with areas high in raw material availability.
Table 5-1. Cortex Percentages for the Late Prehistoric Component and Lower Component

\begin{tabular}{|c|c|c|c|}
\hline Cortex $\%$ & Late Prehistoric & Lower & Total Count \\
\hline $0 \%$ & $257(86 \%)$ & $73(82 \%)$ & 330 \\
\hline $1-50 \%$ & $28(9 \%)$ & $14(16 \%)$ & 42 \\
\hline $51-100 \%$ & $14(5 \%)$ & $2(2 \%)$ & 16 \\
\hline Total Count & 299 & 89 & 388 \\
\hline
\end{tabular}

\section{Maximum Dimension}

The maximum dimension of each debitage specimen was also noted. As with cortex percentage, the size of debitage is indicative of reduction processes. In general, the smaller the piece of debitage the closer to completion the end product is assumed to be. The average size of specimens from the entire assemblage was 18 millimeters $(\mathrm{mm})$. A comparison of size between the two components, points to smaller specimens $(8 \mathrm{~mm})$ from the Toyah component and slightly larger specimens $(10 \mathrm{~mm})$ from the lower component.

\section{Patina}

Another attribute recorded for each debitage specimen was the absence or presence of patina. Typically, the amount of patina on a specimen can be used to infer age. It is assumed that the presence of patina indicates older material. Research has shown that at several sites the occurrence of patinated material increases with depth (Frederick et al. 1994; Bement 1989). Thirty percent of the assemblage is patinated, $22 \%$ from the Toyah component and $57 \%$ of the lower component. A chi-square test of specimens with or without patina by component (Table 5-2) proves to be significant (39.56, $\mathrm{p}<.000, \mathrm{df}=1)$. However, in a two by two contingency table the determination of which cell is contributing to the significance is not discernable.

Table 5-2. Presence/Absence of Patina by Component

\begin{tabular}{|c|c|c|c|c|}
\hline Component & & Absent & Present & Total \\
\hline \multirow{2}{*}{$\begin{array}{c}\text { Late } \\
\text { Prehistoric }\end{array}$} & Count & 232 & 67 & 299 \\
\cline { 2 - 5 } & Adjusted Residual & 6.3 & -6.3 & \\
\hline \multirow{2}{*}{ Lower } & Count & 38 & 51 & 89 \\
\cline { 2 - 5 } & Adjusted Residual & -6.3 & 6.3 & \\
\hline & Total & 270 & 118 & 388 \\
\hline
\end{tabular}




\section{Breakage Patterns}

In order to examine the variation in breakage patterns, the condition of each specimen was noted as being complete (cmp), platform bearing (pfb), medial/distal (md) or angular debris. This attribute can be used to determine reduction activities (Sullivan and Rozen 1985) and raw material type (Amick and Mauldin 1997). Table 5-3 shows flake fragment percentages based on experimental data for tool versus core reduction assemblages. The majority of the flakes from 41BX1764 are medial distal (md) flakes (55\%). Thirty-three percent of the flakes are complete, $12 \%$ are platform bearing and $0.3 \%$ of the specimens are angular debris.

Adjusted residuals provide information on the contribution of each individual cell to the overall contingency table. Adjusted residual values exceeding an absolute value of \pm 1.96 suggest that the cell differences are statistically significant at a .05 level of probability. When comparing breakage patterns according to cultural components complete flakes are over represented (adjusted residual -2.3) in the Toyah Phase component and under represented (adjusted residual 2.3) in the lower component (Table 5-4).

Table 5-3. Flake Fragment Percentages for Tool versus Core Reduction Assemblages

\begin{tabular}{|c|c|c|c|}
\hline & $\begin{array}{c}\text { Sullivan and } \\
\text { Roze (1985) }\end{array}$ & $\begin{array}{c}\text { Amick and } \\
\text { Mauldin (1997) }\end{array}$ & $\begin{array}{c}\text { Prentice and } \\
\text { Romansky (1989) }\end{array}$ \\
\hline Tool & & & \\
\hline CMP & 22 & 41.7 & 33 \\
\hline PRB & 17 & 19.6 & 26 \\
\hline MD & 53 & 37.8 & 36 \\
\hline${ }^{*}$ NF & 8 & 0.9 & 5 \\
\hline Core & & & 22 \\
\hline CMP & 65 & 35.6 & 23 \\
\hline PRB & 8 & 21.3 & 24 \\
\hline MD & 20 & 40.7 & 32 \\
\hline *NF & 7 & 2.3 & \\
\hline *angular debris & & \\
\hline
\end{tabular}

Table 5-4. Breakage Patterns by Component

\begin{tabular}{|c|c|c|c|c|c|c|}
\hline Component & & Angular & Complete & $\begin{array}{c}\text { Medial/ } \\
\text { Distal }\end{array}$ & $\begin{array}{c}\text { Platform } \\
\text { Bearing }\end{array}$ & Total \\
\hline $\begin{array}{c}\text { Late } \\
\text { Prehistoric }\end{array}$ & Count & $1(1 \%)$ & $89(29 \%)$ & $\begin{array}{c}171 \\
(57 \%)\end{array}$ & $\begin{array}{c}38 \\
(13 \%)\end{array}$ & 299 \\
\hline & $\begin{array}{c}\text { Adjusted } \\
\text { Residual }\end{array}$ & 0.5 & $-\mathbf{2 . 3}$ & 1.5 & 1 & \\
\hline Lower & Count & 0 & $38(43 \%)$ & $\begin{array}{c}43 \\
(48 \%)\end{array}$ & $8(9 \%)$ & 89 \\
\hline & $\begin{array}{c}\text { Adjusted } \\
\text { Residual }\end{array}$ & -0.5 & $\mathbf{2 . 3}$ & -1.5 & -1 & \\
\hline Total & & 1 & 127 & 214 & 46 & 388 \\
\hline
\end{tabular}

The percentage of breakage patterns for the Toyah component reflected those reported by Sullivan and Rozen (1985) for tool assemblages. The lower component is similar to Amick and Mauldin's (1997) core assemblage.

\section{Lithic Tools and Cores}

Ten lithic tools and cores were recovered during the testing of 41BX1764. Attributes recorded for lithic tools included dimension (length, width and thickness), cortex percentage, and break type (i.e. manufacture, use or post-depositional). Four of the tools recovered from the site are bifaces. Three bifaces were from Test Unit 2 from Levels 3, 7 and 10. The specimen from Level 3 exhibits a manufacture break and the specimen from Level 10 has two breaks, one post-depositional and the other indeterminate. The biface specimen from Level 7 is complete and heavily patinated (Figure $5-1 \mathrm{a}$ ) with a width to thickness ratio is $4: 1$. One complete biface was recovered from Test Unit 6, Level 9 (Figure 5-1b). It is also heavily patinated with a width to thickness ratio of 3:6.

Three of the lithic tools are informal flake tools. One flake tool, recovered from Test Unit 4, Level 2, contains flake scars indicating use-wear on its ventral side. A flake tool, recovered from Test Unit 7, Level 3, exhibits evidence of use-wear on its dorsal side and is heavily patinated. One retouched flake was recovered from Test Unit 6, Level 7 and is worked on its dorsal side.

A beveled knife fragment was the only diagnostic tool recovered from test unit excavations. The specimen was recovered from Test Unit 1, Level 4 (Figure 5-1c). It appears that the tool was broken during manufacture. This tool type is typically associated with the Toyah Phase.

Two cores were recovered, one from TU 1 (Level 2) and the other from TU 7 (Level 5). The core specimen from TU 1 is multi-directional and small, measuring $26 \mathrm{~mm}$ by $36 \mathrm{~mm}$. The core from TU 7 is larger, measuring $112 \mathrm{~mm}$ by $84 \mathrm{~mm}$ in size. It is also multi-directional and patinated.

\section{Summary}

The goal of the analysis was to observe any temporal or technological patterning in the lithic assemblage. Four attributes, cortex percentage, maximum dimension, patina and breakage, were studied as part of the debitage analysis. An examination of the percentage of cortex on debitage specimens revealed a high frequency of tertiary flakes in the overall site assemblage and in each of the two separate components. This correlates with the model developed by 


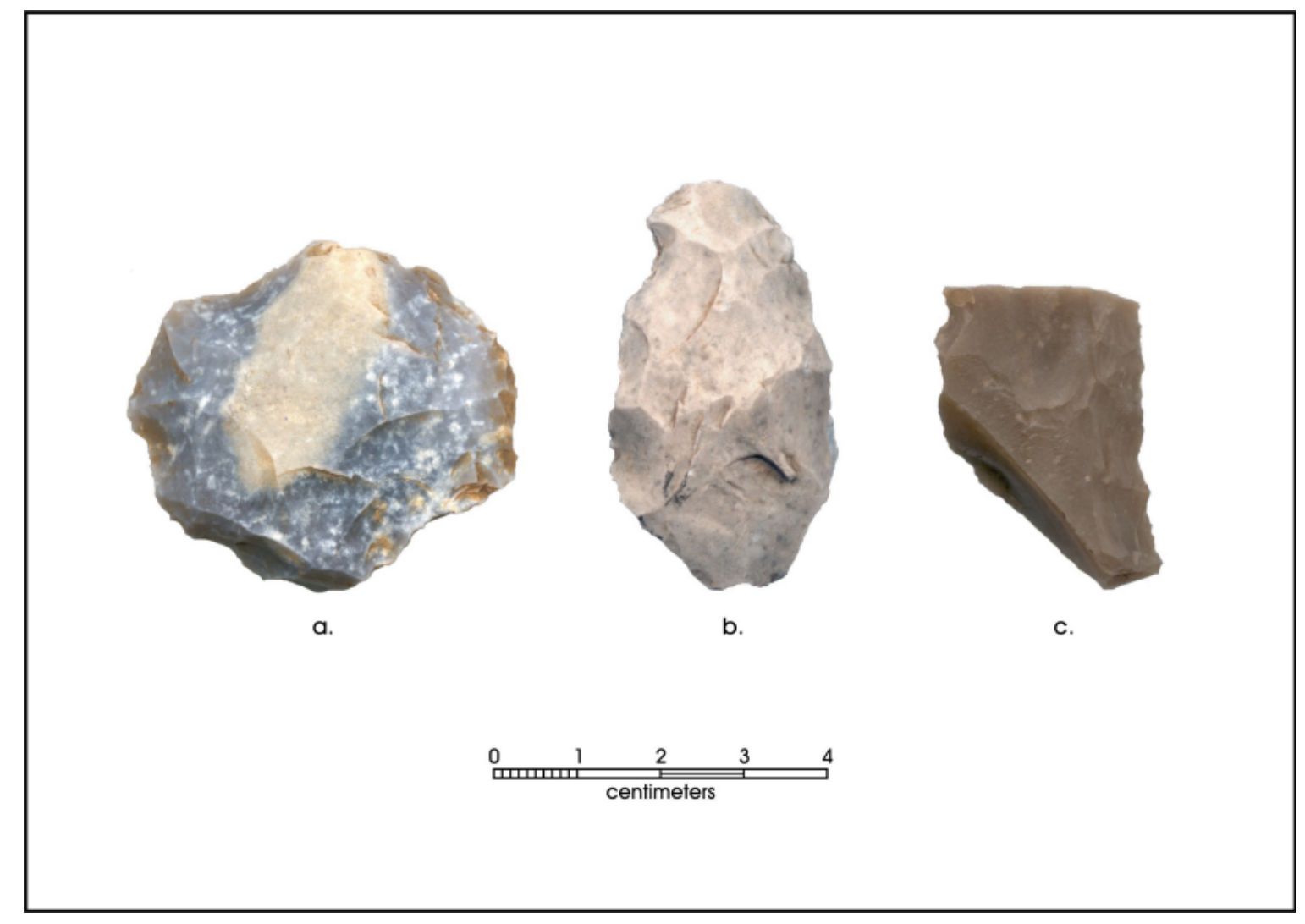

Figure 5-1. Lithic tools recovered from test unit excavations: a-b)biface, c) fragment of beveled knife.

Mauldin and Figueroa (2005); sites in areas with high raw material availability will exhibit a high percentage of noncortical (tertiary) flakes.

The maximum dimension of debitage varies slightly between the two components. The Toyah Phase assemblage is, on average, $2 \mathrm{~mm}$ smaller than the lower component. Statistical tests on the presence or absence of patina on debitage between components proved to be significant. The lower component contains a higher percentage of patinated debitage than the Toyah Phase component. The breakage patterns between the Toyah Phase component and the lower component indicate two different reduction strategies. The Toyah Phase component exhibits similar patterns to a tool assemblage, while the lower component mimics patterns of a core assemblage.
The diagnostic beveled knife aided in identifying the Toyah Phase component. Six tools were encountered in the Toyah Phase component, while four were associated with the lower component. Formal and informal tools were identified in both components. Complete bifaces were only recovered from the lower component.

Although no patterns were discernable upon examination of lithic tools, patterns were evident in the debitage assemblage. Differences between the Toyah Phase component and the lower components were observed. Notably, the examination of breakage patterns suggests that two different reduction strategies were practiced over time. 



\section{Chapter 6: Conclusions and Recommendations}

The CAR conducted NRHP eligibility testing of site 41BX1764 in August 2008. The site was identified during the Salado Creek Greenway survey in February 2008 (Figueroa 2008). The CAR recommended eligibility testing of the site due to proposed impacts associated with the Salado Creek Greenway project. The THC concurred with the CAR's recommendations for eligibility testing of 41BX1764.

The eligibility testing of 41BX1764 included the excavation of seven 1-x-1 m test units. As a result, $5.0 \mathrm{~m}^{3}$ of soil was excavated and over 600 artifacts were recovered. No features were encountered during testing. Excavations indicated that an existing trail has impacted site deposits in the eastern portion of the site. Other impacts to the site include soil erosion associated with an ephemeral drainage that bisects the site. The central portion of the site, where Test Units 6 and 7 were placed, contained the highest density of artifacts. Test units exhibiting the lowest density of artifacts were located on the north-eastern portion of the site on the existing trail.

One diagnostic artifact, a beveled knife associated with the Toyah Phase, was recovered from test unit excavations. The beveled knife along with a Perdiz point, recovered from the initial archaeological survey, provide a temporal association for the deposit. The Toyah component encompasses the first $50 \mathrm{cmbs}$ of the site. Below this component, a lower component of unknown age is evident. An analysis of the lithic debitage indicates differences, particularly in breakage patterns, between the two components. The Toyah Phase deposit has been impacted by erosion and artificial impacts associated with the existing trail. The lower component appears to be in secondary context resulting from high energy depositional events.

Site 41BX1764 is a multi-component site. The disturbance of the Toyah Phase component, coupled with a lack of features and intact deposits, hinders the research potential of the site. Therefore, the CAR does not recommend the site as eligible for listing in the NRHP nor as an SAL. We suggest that proposed impacts to 41BX1764 associated with the Salado Greenway project can proceed as planned. 



\section{References Cited}

Amick, D. and R.P. Mauldin

1997 Effects of Raw Material on Flake Breakage Patterns. Lithic Technology 22 (1):18-32.

Andrefsky, W., Jr.

1998 Lithics: Macroscopic Approaches to Analysis. University Press, Cambridge.

Bement, L.C.

1989 Excavations at 41BP19: The Kennedy Bluffs Site, Bastrop County, Texas. Texas Archaeological Research Laboratory, The University of Texas at Austin. Contract Reports in Archaeology Report No. 5. Highway Design Division, Texas State Department of Highways and Public Transportation, Austin.

Black, S.L.

1989 Environmental Setting. In From the Gulf Coast to the Rio Grande: Human Adaptations in Central, South and Lower Pecos Texas., edited by T.R. Hester, S.L. Black, D.G. Steele, B.W. Olive, A.A. Fox, K.J. Reinhard and L.C. Bement, pp. 17-38. Research Series No. 33. Arkansas Archeological Survey, Fayetteville.

Black, S.L. and D.G. Creel

1997 The Central Texas Burned Rock Midden Reconsidered. In Hot Rock Cooking on the Greater Edwards Plateau: Four Burned Rock Midden Sites in West Central Texas. edited by S. Black, L.W. Ellis, D.G. Creel, and G.T. Goode, pp.269305. Studies in Archeology 2. Texas Archeological Research Laboratory, The University of Texas at Austin.

Chapa, J.B.

1997 Historia del Nuevo Reino de Leon. In Texas and Northeastern Mexico, 1630-1690. edited by J. Bautista Chapa and W. C. Foster, p. 91. Translated by N. F. Brierly, The University of Texas Press, Austin.

Collins, M.B.

1995 Forty Years of Archeology in Central Texas. Bulletin of the Texas Archaeological Society 66:361-400.

Córdova, K.J., B.K. Moses, and R.P. Mauldin

2005 Records and Collections Assessment of Previous Investigations at Sites $41 B X 17$ and 41 BX271 (Granberg I and II) within the ROW of Loop 410 East at Salado Creek, San Antonio, Bexar County, Texas. Report on file at the Center for Archaeological Research, The University of Texas at San Antonio.

Figueroa, A.L.

2008 An Intensive Pedestrian Archaeological Survey of the Salado Creek Greenway, Wetmore Avenue to Eisenhauer Road, San Antonio, Bexar County, Texas. Archaeological Report, No. 395. Center for Archaeological Research, The University of Texas at San Antonio.

Figueroa, A.L and J.L. Thompson

2005 Intensive Pedestrian Survey of the Three Tracts to be Impacted by the Planned Expansion of the San Antonio International Airport, Bexar County, Texas. Archaeological Report, No. 357. Center for Archaeological Research, The University of Texas at San Antonio.

Frederick, C.D., M.D. Glascock, H. Neff and C.M. Stevenson

1994 Evaluation of Chert Patination as a Dating Technique: A Case Study from Fort Hood, Texas. Mariah Associates, Austin. Research Report No. 31, Archaeological Resource Management Series. U.S. Army, Fort Hood. 
Hester, T.R.

1977 Excavations at St. Mary's Hall (41BX229): A Buried Plainview Campsite in South Central Texas. Paper Presented at the Texas Archeological Society, Arlington, October 28-30.

1995 The Prehistory of South Texas. Bulletin of the Texas Archeological Society 66:427-459.

Magne, M.P.R.

1989 Lithic Reduction Stages and Assemblages Formation Processes. In Experiments in Lithic Technology, edited by D.S. Amick and R.P. Mauldin, pp.15-31. British Archaeological Reports International Series 528, Oxford.

Mauldin, R.P. and A.L. Figueroa

2005 Data Recovery Excavations at 41PR44, Fort Wolters, Parker County, Texas. Archaeological Report, No. 369. The University of Texas at San Antonio.

Munoz, C.M.

2008 An Intensive Pedestrain Archaeological Survey of the Salado Creek Greenway, Wetmore to Eisenhauer Road, San Antonio, Bexar County, Texas, Phase I: N.E. Loop 410 to Eisenhauer Road. Technical Report, No. 8. Center for Archaeological Research, The University of Texas at San Antonio.

Perttula, T.K., M.R. Miller, R.A. Ricklis, D.J. Prikryl, and C. Lintz

1995 Prehistoric and Historic Aboriginal Ceramics in Texas. Bulletin of the Texas Archeological Society 66:175-235.

Potter, D., and S. Black

1995 Archeology Along the Wurzbach Parkway: Module 2 Initial Testing and Evaluation of Five Prehistoric Sites in the Upper Salado Watershed, Bexar County, Texas. Studies in Archeology 18. Texas Archeology Research Laboratory, The University of Texas at Austin.

Potter, D., S.L. Black and K. Jolly

1995 Archeology along the Wurzbach Parkway: Module 1 Introduction, Conceptual Framework, and Contexts of Archeological Investigations in Bexar County, South-Central Texas. Studies in Archeology 17. Texas Archeology Research Laboratory, The University of Texas at Austin.

Prentiss, W.C. and E.J. Romanski

1989 Experimental Evaluation of Sullivan and Rozen's Debitage Typology. In Experiments in Lithic Technology, edited by D.S. Amick and R.P. Mauldin, pp. 89-99. British Archaeological Reports International Series 528, Oxford.

Ricklis, R.A.

1992 The Spread of the Late Prehistoric Bison Hunting Complex: Evidence from the South-Central Coastal Prairie of Texas. Plains Anthropologist 37(140):261-273.

Schuetz, M.K.

1966 The Granberg Site: An Archaic Indian Habitation in Bexar County, Texas. Studies No. 1. Witte Memorial Museum, San Antonio.

Sullivan, A.P., III and K. Rozen

1985 Debitage Analysis and Archaeological Intrepretation. American Antiquity 50 (4):755-779.

Taylor, F.B., R.B. Hailey and D. L. Richmond

1991 Survey, Bexar County, Texas. Soil Conservation Service, U. S. Department of Agriculture, Washington D. C. 
Texas Historical Commission (THC)

2008 Texas Archeological Sites Atlas, http://www.nueces.thc.state.tx.us/>, accessed September 2008.

Thompson, J.L.

2006 National Register of Historic Places/State Archeological Landmark Eligibility Testing of the Granberg Site (41BX17). Manuscript on file. The Center for Archaeological Research, The University of Texas San Antonio.

Turner, S.E., and T.R. Hester

1993 Stone Artifacts of Texas Indians. Second Edition. Texas Monthly and Gulf Publishing Company, Houston.

Vines, R.A.

1960 Trees, Shrubs, and Woody Vines of the Southwest. University of Texas Press, Austin. 
